January 2019

\title{
Delay, Deny, Wait Till They Die: Balancing Veterans' Rights and Non-Adversarial Procedures in the VA Disability Benefits System
}

Hugh McClean

University of Baltimore

\section{Recommended Citation}

Hugh McClean, Delay, Deny, Wait Till They Die: Balancing Veterans' Rights and Non-Adversarial Procedures in the VA Disability Benefits System, 72 SMU L. REV. 277 (2019)

https://scholar.smu.edu/smulr/vol72/iss2/10 


\title{
Delay, Deny, Wait Till They Die: Balancing Veterans' Rights And Non-Adversarial Procedures IN THE VA DiSABILITY Benefits System
}

\author{
Hugh B. McClean*
}

\begin{abstract}
The refrain "Delay, Deny, Wait Till They Die" is more than a slogan for disabled American veterans. It is a battle cry for soldiers, sailors, and airmen who have long put aside their armaments but remain entangled in the unending appeals process of the Department of Veterans Affairs' (VA) disability benefits system. When Congress created a system for the fair and equitable distribution of military benefits, it did so with the intent that the system be non-adversarial. Congress did not want disabled veterans pitted against the nation that they had sought to defend in litigation over disability benefits. However, defining the contours of that non-adversarial system has proven to be more difficult than Congress ever anticipated. The paternalistic and protective features of the system designed to insulate veterans from the burdens of adversarial litigation have left veterans without legal recourse to address system failures. Using the VA's process for developing expert medical testimony as an example, this article examines the costs and benefits of the non-adversarial process and argues that adversarial procedures must be woven into the fabric of the veteran-friendly system to ensure that veterans' rights are protected. This article concludes that, without adversarial processes to compliment the veteran-friendly rules, the VA model relegates disabled veterans to a substandard process for adjudicating disability benefits.
\end{abstract}

* Assistant Professor and Director, Bob Parsons Veterans Advocacy Clinic, University of Baltimore School of Law. LL.M. 2011, George Washington University Law School; J.D. 2002, Case Western Reserve University School of Law; B.A. 1996, Miami University. Thanks to Michelle Ewert, Michele Gilman, Leigh Goodmark, Audrey McFarlane, James Ridgway, Ann Shalleck, and Stacey-Rae Simcox for their feedback, as well as to the clinical faculty and teaching fellows at the University of Baltimore School of Law. Special thanks to Melissa, Vincent, Jude, and Lillian for their love and support, and to our veterans who have sacrificed much for our country. 


\section{TABLE OF CONTENTS}

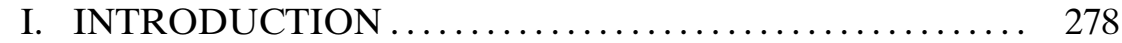

II. AN ADMINISTRATIVE SYSTEM IN CRISIS ......... 282

A. Overview of the Veterans' Benefits System ..... 282

B. Veteran-Friendly Canons and the NonAdversarial Benefits System................ 285

C. The Harmful Effects of the Non-Adversarial System: A Case Study ...................... 288

D. The Expert Testimony Crisis.................. 291

III. WHY JUDICIAL REVIEW HAS FAILED TO PROTECT VETERANS' INTERESTS ............... 295

A. The Limited Role of Appellate Courts ......... 295

B. Deference to Congress and Limited Due

Process for Disabled Veterans ............... 297

C. The VA's Duty to Assist Failures ............. 303

IV. BALANCING THE NON-ADVERSARIAL SYSTEM WITH ADVERSARIAL PROCEDURES ........... 307

A. Rights of Claimants in Other Disability

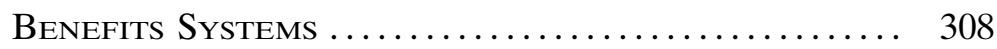

B. The Adoption of APA Hearing Procedures for VA Medical Exams ....................... 311

C. Other Proposals for Resolving Inefficiency in THE VA SYSTEM .............................. 313

V. CONCLUSION $\ldots \ldots \ldots \ldots \ldots \ldots \ldots \ldots \ldots \ldots \ldots \ldots \ldots \ldots \ldots \ldots$

\section{INTRODUCTION}

7 He Department of Veterans Affairs (VA) is experiencing the greatest crisis it has encountered since its establishment as a federal agency in $1930 .{ }^{1}$ The VA faces a crippling claims backlog, ${ }^{2}$ high turnover in executive leadership and frontline positions, ${ }^{3}$ and morale

1. See About VA, U.S. Dep't of Veterans Affairs (Aug. 6, 2018), https://www.va .gov/about_va/vahistory.asp [https://perma.cc/47CQ-4MV2]. The VA is the second largest department after the Department of Defense. See VA's Administrations, U.S. DeP'T of Veterans AfFAIRs (Mar. 21, 2018), https://www.ruralhealth.va.gov/aboutus/structure.asp [https://perma.cc/KAN3-YL2P]. The VA is composed of three divisions: the Veterans Health Administration (VHA); the National Cemetery Administration (NCA); and the Veterans Benefits Administration (VBA). Id. This article focuses on the VBA, the division that manages veterans' benefits.

2. See Bd. of Veterans' Appeals, Annual Report: Fiscal Year 2017, U.S. Dep't of VETERANS AfFAIRS 12 (2017), https://www.bva.va.gov/docs/Chairmans_Annual_Rpts/ BVA2017AR.pdf [https://perma.cc/W2MY-EUWU] [hereinafter Bd. of Veterans' Appeals, Annual Report 2017]. The VA appeals inventory stands at over 471,000 appeals. Id. at 21. In 2017, the Board of Veterans' Appeals issued decisions in 52,661 cases, though it received 90,327 new cases. Id. at 13 . Veterans currently wait an average of three years for a Board decision. $I d$.

3. Secretary Robert L. Wilkie, Jr. was sworn in as the tenth United States Secretary of the VA on July 30, 2018. Senior Executive Biography: Robert Wilkie, U.S. Dep't of Veterans AfFaIRs, https://www.va.gov/opa/bios/docs/wilkie.pdf [https://perma.cc/3T4CW6PM] (last visited Mar. 3, 2019). He is the third Secretary to be appointed to the position 
problems stemming from scandals that are exhausting its more than 377,000 employees. ${ }^{4}$ This confluence of factors, amidst a polarizing national debate on the privatization of veterans' health care, has left the VA reeling. As one VA physician described the situation, "The V.A. seems

in the last four years. See Donovan Slack \& Dennis Wagner, VA Failures Endured Through Three Secretaries, USA TodAy (Mar. 29, 2018, 5:33 PM), https://www.usatoday.com/story/ news/politics/2018/03/29/veterans-affairs-failures-go-beyond-ousted-secoutlive-three-secre taries-soon-four-including-david-sh/470573002/ [https://perma.cc/PSG7-CMF6]; see also Mohana Ravindranath, Wilkie Overwhelmingly Confirmed as VA Secretary, PoLitico (July 24, 2018, 10:00 AM), https://www.politico.com/newsletters/morning-ehealth/2018/07/24/wil kie-overwhelmingly-confirmed-as-va-secretary-295130 [https://perma.cc/L5PJ-3GDG] (discussing critics' concerns that Secretary Wilkie will privatize VA health care); Leo Shane III, 3 Looming Questions for Robert Wilkie's Confirmation Hearing, Military Times (June 20，2018), https://www.militarytimes.com/veterans/2018/06/20/three-looming-ques tions-for-robert-wilkies-va-confirmation-hearing/ [https://perma.cc/559M-N38Q] (discussing vacancies at all levels of the VA).

4. See Lisa Rein, 'Failure is Not An Option': VA Nominee Robert Wilkie Told to Fix the Agency's Morale Crisis, WAsH. Post (June 27, 2018), https://www.washingtonpost.com/ politics/robert-wilkie-trumps-pick-for-va-secretary-to-face-tough-questions-on-his-past/ 2018/06/27/106863f6-798d-11e8-80be-6d32e182a3bc_story.html?utm_term=.ff44f301e82c [https://perma.cc/RT9Y-GCJ6]; see also Curt Devine, 307,000 Veterans May Have Died Awaiting Veterans Affairs Health Care, Report Says, CNN (Sept. 3, 2015, 11:38 AM), https:/ /www.cnn.com/2015/09/02/politics/va-inspector-general-report/index.html [https://perma.cc/ AA3M-G4RG]; Phil McCausland, Veterans Haven't Received GI Bill Benefits for Months Due to Ongoing IT Issues at VA, NBC News (Nov. 11, 2018, 11:00 AM), https://www .nbcnews.com/news/us-news/veterans-haven-t-receive-gi-bill-benefits-months-due-ongoingn934696 [https://perma.cc/SW5Y-UZK9] (attributing the VA's failure to pay education benefits to lack of employee retention and consistent leadership); Paul Muschick, Veterans Died While Waiting For Slow-Moving Benefits Appeals, The Morning Call (Mar. 30, 2018, 8:00 AM), http://www.mcall.com/opinion/muschick/mc-opi-veterans-die-while-wait ing-for-va-benefits-muschick-20180329-story.html\# [https://perma.cc/K4CB-NU8C]; Katie Zezima, Everything You Need to Know About the VA-and the Scandals Engulfing It, WAsH. Post (May 30, 2014), https://www.washingtonpost.com/news/the-fix/wp/2014/05/21/ a-guide-to-the-va-and-the-scandals-engulfing-it/?utm_term=.9a8f76cab9f9 [https://perma .cc/ZN4U-PWPE] (discussing the VA's false record keeping, long wait lists for care, and "mismanaged" programs and facilities). In 2014, the VHA was involved in a secret wait list scandal that was discovered at the Phoenix, Arizona VA hospital. Richard A. Oppell, Jr. \& Michael D. Shear, Severe Report Finds V.A. Hid Waiting Lists at Hospitals, N.Y. Times (May 28, 2014), https://www.nytimes.com/2014/05/29/us/va-report-confirms-improper-wait ing-lists-at-phoenix-center.html [https://perma.cc/LY6N-F3RC]. Similar problems were later discovered at other VA facilities. Id. At the time, the VA Inspector General (IG) reported that more than 1,700 veterans on secret waiting lists waited an average of 115 days for primary care appointments. $I d$. In a later report, the IG found that out of about 800,000 records that were stalled in the VA's health care enrollment system, more than 307,000 records belonged to veterans who had died months or years earlier. Devine, supra note 4 . The IG later confirmed that about 1,100 veterans actively seeking health care had died while waiting for their appointments. U.S. Dep'T of Veterans AfFairs, OfFice of Inspector Gen., 16-01750-79, Veterans Benefits Administration: Review of Timeliness of the Appeals Process 12 (Mar. 28, 2018) [hereinafter Review of Timeliness of Appeals Process]. The scandal led to the resignation of then VA Secretary Eric Shinseki and prompted Congress to pass the "Choice Act." See Veterans Access, Choice, and Accountability Act of 2014, Pub. L. No. 113-146, 128 Stat. 1754 (2014) (codified as amended in scattered sections of 38 U.S.C.). The NCA, a division of the VA, has also experienced problems. See Christian Davenport, Burial Problems Found at VA Cemeteries, WAsh. Post (Jan. 23, 2012), https://www.washingtonpost.com/local/burial-problems-foundat-va-cemeteries/2012/01/23/gIQAYXLFMQ_story.html?utm_term=.570b4a2d2ae3 [https:// perma.cc/AE3D-QA9W] (following an FBI investigation of the Army-run Arlington National Cemetery, the NCA conducted a review of its cemeteries in 2012 and found scores of misplaced headstones and people buried in the wrong location). 
like a jumbo jet over the Atlantic without a pilot right now ... [t]here is chaos in the cockpit, and there is chaos in the cabin, too." 5

Media attention has rightly focused on secret VA hospital waiting lists and veterans who have died while waiting for medical care. ${ }^{6}$ But a lesserknown problem exists within another division of the VA that is affecting thousands of disabled veterans, many of whom are seriously ill and are waiting for resolution of their disability benefits claims. ${ }^{7}$ Within the Veterans Benefits Administration (VBA), disabled veterans are being retraumatized by an overburdened and dysfunctional benefits system that Congress intended to be "veteran-friendly," but in fact prevents veterans from obtaining the benefits they earned in service. ${ }^{8}$

Congress created an informal and flexible benefits system so that veterans would not be embroiled in adversarial litigation against the government they fought to defend. ${ }^{9}$ As such, the VBA distributes benefits pursuant to statutes and regulations that are uniformly described as "nonadversarial" by the VA adjudicators and judges who decide veterans' benefits cases. ${ }^{10}$ The rules of evidence for VA hearings are relaxed, there is no statute of limitations on filing claims, and veterans can endlessly appeal denied claims upon a showing of new and relevant evidence. ${ }^{11}$ Many veterans and their advocates appreciate the informality of the process, until their claims are denied.

The problem with the non-adversarial process is that the VA often ignores or misapplies its regulations. When this happens, veterans have limited remedies to challenge VA errors. Of course, veterans have the right to appeal adverse agency decisions, but the average administrative appeal takes almost five years to reach a resolution. ${ }^{12}$ Appeals to the specialized

5. Dave Philipps \& Nicholas Fandos, V.A. Medical System Staggers as Chaos Engulfs Its Leadership, N.Y. Times (May 4, 2018), https://www.nytimes.com/2018/05/04/us/politics/ va-medical-system-chaos.html [https://perma.cc/8MLP-PZ34].

6. See Zezima, supra note 4.

7. See 60 Minutes: Why the VA Frustrates Veterans (CBS television broadcast Jan. 3, 2010), https://www.cbsnews.com/news/why-the-va-frustrates-veterans/ [https://perma.cc/ 46MS-5CRP].

8. See Leo Shane III, Watchdog Report: The VA Benefits Backlog is Higher Than Officials Say, Military Times (Sept. 10, 2018), https://www.militarytimes.com/news/2018/ 09/10/watchdog-report-the-va-benefits-backlog-is-higher-than-officials-say/ [https://perma .cc/E2V5-X78L].

9. See Hodge v. West, 155 F.3d 1356, 1362 (Fed. Cir. 1998) (an often cited passage, Judge Michel noted that "the character of the veterans' benefits statutes is strongly and uniquely pro-claimant").

10. Id.

11. See Veterans Appeals Improvement and Modernization Act, Pub. L. No. 115-55, 131 Stat. 1105 (2017) (codified as amended in scattered sections of 38 U.S.C.).

12. See Bd. of Veterans' Appeals, Annual Report: Fiscal Year 2018, U.S. DeP'T of Veterans AfFairs 25 (2018), https://www.bva.va.gov/docs/Chairmans_Annual_Rpts/ BVA2018AR.pdf [https://perma.cc/M3TM-QV77] [hereinafter Bd. of Veterans' Appeals, Annual Report 2018]; see also U.S. Dep't of Veterans Affairs, Veterans Benefits Admin., Appeals Modernization 3 (May 2018), https://www.bva.va.gov/docs/Appeals Modernization_Brief_May2018.pdf [https://perma.cc/XQ75-QW7E] ("For those appeals that were decided by the Board of Veterans Appeals in FY 2016, on average, Veterans waited at least 7 years from filing their [notice of appeal] until the Board decision issued that year."). 
courts reviewing VA decisions can take up to seven years. ${ }^{13}$ Homeless, mentally ill, and terminally ill veterans cannot afford such delays. According to the VA Office of the Inspector General, approximately 1,100 veterans died in 2016 after waiting more than a year for the VA to rule on their appeals for benefits. ${ }^{14}$ The maxim "[d]elay, deny, hope they die" has unfortunately become a reality for many disabled veterans. ${ }^{15}$

In 2017, the Supreme Court examined the VA's non-adversarial process in a case called Mathis $v$. Shulkin. ${ }^{16}$ In his petition for a writ of certiorari to the Supreme Court, Mr. Mathis challenged an evidentiary rule that presumes all VA medical providers are competent to issue medical opinions regardless of the case or claimed medical condition. ${ }^{17}$ The Supreme Court denied Mr. Mathis's petition for a writ of certiorari, though two Justices issued statements questioning the VA's process for resolving veterans' challenges to the competency of VA medical examiners. ${ }^{18}$ Justice Gorsuch noted that the rule lacked a statutory or regulatory basis and that it contravened the VA's duty to assist veterans. ${ }^{19}$ Justice Sotomayor called the veteran's situation "a catch-22," referring to the process by which a veteran must make a specific objection to an examiner's competence without the VA providing any information about an examiner's credentials as a matter of course. ${ }^{20}$ She invited the lower courts and the VA to "continue their dialogue over whether the current system for adjudicating veterans' disability claims can be squared with the VA's statutory obligations to assist veterans in the development of their disability claims." 21 This article takes up Justice Sotomayor's invitation by analyzing the rights of veterans and steps the VA can take to ensure timely and accurate receipt of benefits.

Part I of this article provides an overview of the veterans' benefits system, including its veteran-friendly features. This article argues that the

13. See U.S. Court of Appeals for Veterans Claims, Annual Report 3 (2017), https://www.uscourts.cavc.gov/documents/FY2017AnnualReport.pdf [https://perma.cc/ 4SRK-AV85] [hereinafter U.S. Court of Veterans Claims Annual Report 2017] (the median time for filing a petition for review by the court to disposition is 1.4 months).

14. Review of Timeliness of Appeals Process, supra note 4, at 12.

15. See Muschick, supra note 4.

16. See Mathis v. McDonald, 643 F. App'x 968 (Fed. Cir. 2016), cert. denied sub nom. Mathis v. Shulkin, 137 S. Ct. 1994 (2017) (Gorsuch, J., dissenting); see also Brief of Law School Veterans Clinics and Attorneys as Amici Curiae in Support of the Petition for a Writ of Certiorari, Mathis, 137 S. Ct. 1994 (No. 16-677), 2016 WL 7451283 [hereinafter Brief in Support of the Petition for a Writ of Certiorari] (clinic students from five law schools, including the University of Baltimore School of Law, Harvard Law School, the University of Missouri School of Law, Syracuse University College of Law, and William and Mary Law School, participated in preparing the brief in support of the petitioner).

17. Mathis, 643 F. App'x at 971.

18. Mathis, 137 S. Ct. at 1994-95 (Sotomayor, J., denying cert.; Gorsuch, J., dissenting) (in a statement accompanying the denial of the petition, Justice Sotomayor explained that the Court denied the petition because Mr. Mathis never requested his examiner's credentials; without the request for the examiner's credentials, and the VA's response to such a request, the Court could not fully review the presumption and the VA's practice).

19. Id. (Gorsuch, J., dissenting).

20. Id. at 1994 (Sotomayor, J., denying cert.).

21. Id. at 1995. 
veteran-friendly regulations are indeed beneficial to veterans, but only when they are applied correctly. This article focuses on the critically important process for developing expert medical testimony to describe how veterans have no recourse in the non-adversarial system when the VA fails to correctly apply its veteran-friendly procedures. Part II examines the reasons why the non-adversarial system has failed veterans, despite its veteran-friendly features. Using the example of expert medical testimony, Part III compares the veterans' benefits system to the Social Security disability and workers' compensation systems, and argues that the adversarial procedures used in these systems should be incorporated into the veterans' benefits system to facilitate adherence to veteran-friendly rules. This article concludes by examining other proposals to modify the system and explains why these proposals fall short of providing veterans with the necessary means to resolve systemic issues.

As it stands, the benefits system subverts veterans' rights and offers no timely mechanisms to correct VA errors. Veterans deserve better than that. The VA must protect the veteran-friendly features of the system by incorporating adversarial measures that will facilitate the proper application of the rules.

\section{AN ADMINISTRATIVE SYSTEM IN CRISIS}

"As I prepare to leave government, I am struck by a recurring thought: It should not be this hard to serve your country." 22

Although the VHA is by far the most well-known division of the VA, the VBA provides benefits to more than 313,441 veterans annually with an estimated total payment of about $\$ 3.78$ billion in benefits awards a year. ${ }^{23}$ This section discusses the laws that govern the VA benefits system, including the veteran-friendly canons that Congress codified to assist veteran claimants.

\section{A. Overview of the Veterans' Benefits System}

The current disability system has its roots in the British and French veterans' benefits systems and, like those systems, primarily serves two purposes. ${ }^{24}$ The first is to care for veterans and their widows and or-

22. David J. Shulkin, Op-Ed, David J. Shulkin: Privatizing the V.A. Will Hurt Veterans, N.Y. TIMES (Mar. 28, 2018), https://www.nytimes.com/2018/03/28/opinion/shulkin-veteransaffairs-privatization.html [https://perma.cc/Y46H-D77H] (Shulkin served as VA secretary under Presidents Obama and Trump, from July 6, 2015, to March 28, 2018).

23. See U.S. Dep't of Veterans Affairs, Veterans Benefits Admin., Annual Benefits Report Fiscal Year 2016: Compensation 4 (2016), https://www.benefits.va .gov/REPORTS/abr/docs/2016_abr.pdf [https://perma.cc/3ZNK-K2YV].

24. See James D. Ridgway, Veterans Law Cases and Theory 6 (West Academic Publishing, 1st ed. 2015); see also About VA, supra note 1. The practice of awarding benefits to injured soldiers dates back to the colonization of North America. The Pilgrims of Plymouth Colony were at war with the Pequot Indians. Recognizing the unique relationship between disabled soldiers and the communities they protect, the Pilgrims passed a law mandating that the Colony support the disabled soldiers. Many years later, the Continental Congress used the promise of disability pensions to encourage enlistments during the Rev- 
phans. ${ }^{25}$ The second is to maintain the security of the United States and the readiness of the U.S. military by providing veterans with benefits earned through service. ${ }^{26}$ The goals of the system are accomplished through a patchwork of statutes and regulations that have developed over the last two centuries. ${ }^{27}$

Various benefits are available to military veterans, though the focus of this article is on disability compensation. Compensation may be awarded to veterans for disabilities resulting from injuries suffered or diseases contracted during military service. ${ }^{28}$ Veterans must meet specific VA eligibility requirements and must provide evidence that their injury or disease is related to military service. ${ }^{29}$ A prima facie case for direct service-connection requires (1) medical evidence that the veteran has a current disability, (2) medical evidence of an in-service incurrence or aggravation of a disease or injury, and (3) medical evidence of a nexus between the claimed in-service disease or injury and the current disability. ${ }^{30}$ Veterans with service-connected injuries or diseases are eligible to receive monthly disability compensation and medical treatment at VA hospitals. ${ }^{31}$

The procedure for claiming and appealing benefits has been likened to a hamster wheel because veterans' claims are developed, denied, appealed, and remanded ad infinitum. ${ }^{32}$ The process begins when a veteran files a claim for benefits with the VA Regional Office. ${ }^{33}$ If the claim is denied, a veteran may file a Notice of Disagreement. ${ }^{34}$ Upon receipt of the Notice of Disagreement, the VA will reconsider the denied claim and issue a Statement of the Case, affirming or reversing the denial decision,

olutionary War. The process for awarding benefits to veterans has undergone dramatic change since that time, though the rationale for awarding benefits remains the same.

25. See Ridgway, supra note 24, at 6; see also President Abraham Lincoln, Second Inaugural Address (Mar. 4, 1865) (transcript available in the Library of Congress) (the VA's motto, "to care for him who shall have borne the battle and for his widow, and his orphan," comes directly from Lincoln's Second Inaugural Address). Lawmakers have introduced legislation to make the motto gender inclusive, but the VA has resisted such bills. See Nikki Wentling, Two House Lawmakers Launch New Effort to Make VA Motto Gender Inclusive, STARs AND STRIPes (Nov. 16, 2018), https://www.stripes.com/news/twohouse-lawmakers-launch-new-effort-to-make-va-motto-gender-inclusive-1.556957 [https:// perma.cc/NGD8-DL2S].

26. RidgWAy, supra note 24 , at 6.

27. See id. at 6-20.

28. See 38 U.S.C. $\$ 1110(2012)$.

29. See 38 U.S.C. $§ 5303($ A) (2012); see also 38 C.F.R $§ 3.304$ (2018).

30. See 38 C.F.R. $\$ 3.303$ (establishing the requirements for direct service-connection). Service-connection may also be proved through other means depending on the injury or disease. See id. $\S 3.303$ (b)-(d). For example, presumptive conditions do not require a nexus between the illness and the event. See id. $\$ 3.303(\mathrm{c})$. Instead, these illnesses rely on statutory presumptions that the injury or disease occurred in service. Id. Other illnesses such as Post-Traumatic Stress Disorder and Military Sexual Trauma require additional evidence of a stressor to establish service-connection. See id. § 3.304(f).

31. See 38 C.F.R. $\S \$ 4.1-4.150$ (2018); see also 38 C.F.R. $§ 17.38$ (2018).

32. See Coburn v. Nicholson, 19 Vet. App. 427, 434 (2006) (Lance, J., dissenting) (finding that repeated remands "perpetuate[] the hamster-wheel reputation of veterans law").

33. See Veterans Benefits Admin., Life Cycle of a VA Appeal, U.S. Dep't of VeterANS AfFAirs (Dec. 22, 2016), https://www.bva.va.gov/docs/Life-Cycle-of-a-VA-AppealFY2016.pdf [https://perma.cc/ELX8-BWMD] [hereinafter Life Cycle of an Appeal].

34. See id:; see also 38 C.F.R. § 20.201 (2018). 
or notify the veteran of some other disposition. ${ }^{35}$ Veterans may appeal final decisions by the Regional Office to the Board of Veterans' Appeals (the Board). ${ }^{36}$ After exhausting these administrative remedies, veterans may appeal to the Court of Appeals for Veterans Claims (Veterans Court), a special Article I court that functions as an appellate court but is situated like a district court beneath the U.S. Court of Appeals for the Federal Circuit. ${ }^{37}$ The bulk of the delay falls within the appellate process, from the Notice of Disagreement to the Board decision. ${ }^{38}$

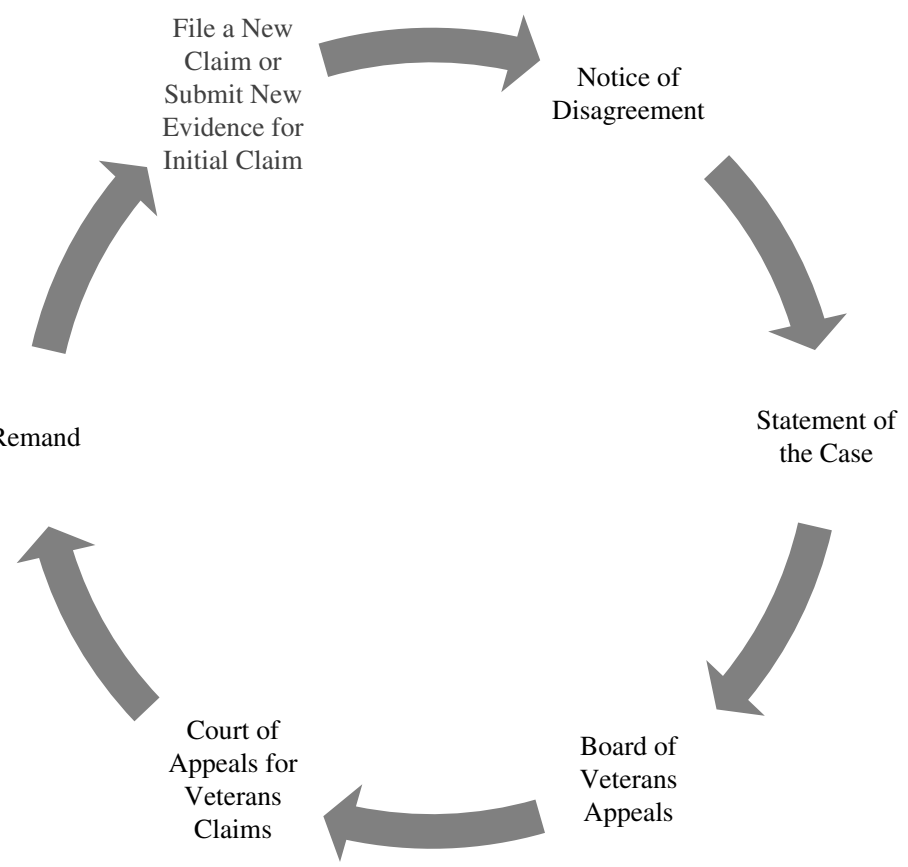

According to the VA, the lifecycle of an appeal, from claim filing to a decision by the Board, takes almost five years. ${ }^{39}$ A decision from the Veterans Court takes an additional year or more. ${ }^{40}$ In all, it can take up to seven years to appeal a claim to the Veterans Court. ${ }^{41}$ Additional delays can extend this time period another two years because about $76 \%$ of appeals decided by the Veterans Court are returned to the VA for further disposition or development. ${ }^{42}$ Although it is difficult to know exactly how

35. See 38 C.F.R. $\$ 19.29$ (2018).

36. See id.; see also 38 C.F.R. § 8.30(c) (2018).

37. See Michael J. Wishnie, "A Boy Gets Into Trouble”: Service Members, Civil Rights, and Veterans' Law Exceptionalism, 97 B.U. L. Rev. 1709, 1730 (2017).

38. See Life Cycle of an Appeal, supra note 33.

39. See id.

40. See id.

41. See id.

42. See U.S. Court of Veterans Claims Annual Report 2017, supra note 13, at 2. 
many veterans are enmeshed in the appeals process, ${ }^{43}$ the VA reported that, in 2016, veterans submitted Notices of Disagreement, the first step in the administrative appeals process, in about $16.6 \%$ of cases. ${ }^{44}$ While this statistic may seem low, the Government Accountability Office (GAO) reviewed data from fiscal years 2010 to 2015 and found that the VA denied $43 \%$ of veterans' initial claims during the six-year period, or about 14 million of 24.7 million initial claims. ${ }^{45}$ Additionally, the GAO found that the denial rates for certain illnesses, such as Gulf War Illness, were about $83 \% .{ }^{46}$ Given the high remand rates of the Board and the Veterans Court, ${ }^{47}$ the data suggests that a significant number of claims that may have been decided in error will never be reviewed.

\section{B. Veteran-Friendly Canons and the Non-Adversarial BENEFITS SySTEM}

The terms "non-adversarial" and "veteran-friendly" are not statutorily defined terms, though courts have commonly used these terms to describe the flexible administrative rules that govern the process. ${ }^{48}$ Courts often refer to the fact that VA counsel does not oppose veterans and their representatives in the administrative claims process, and that the VA has a statutory duty to assist veterans in establishing their claims. ${ }^{49}$ In this respect, the system is similar to the Social Security disability system's non-adversarial model of adjudicating claims. ${ }^{50}$ However, the veterans' system has a few features that make it unique.

The hallmark of the veterans' benefits system is its liberal burden of proof standard for establishing benefits. ${ }^{51}$ Veterans have the burden of proving that their disability is "at least as likely as not" related to military service. ${ }^{52}$ The VA describes the standard as equal to or greater than $50 \%$,

43. See U.S. Dep't of Veterans Affairs, Veterans Benefits Admin., Annual Benefits Report Fiscal Year 2017: Compensation 25 (Sept. 30, 2017), https://www .benefits.va.gov/REPORTS/abr/docs/FY17-Compensation.pdf [https://perma.cc/K68RSWBJ] (VA reports "information on the number of service-connected disabilities, as opposed to the number of Veterans with those [disabilities].").

44. See Life Cycle of an Appeal, supra note 33.

45. U.S. Gov't Accountability Office, GAO-17-511, Gulf War Illness: Improvements Needed for VA to Better Understand, Process, and Communicate Decisions on Claims 18 (June 2017).

46. Id.

47. See Bd. of Veterans' Appeals, Annual Report 2018, supra note 12, at 31. In 2018, the Board granted $36 \%$ and remanded $39 \%$ of the claims on appeal. Id. The Court of Appeals for Veterans Claims remanded about $76 \%$ of the claims. See U.S. CourT OF VETerans Claims Annual Report 2017, supra note 13, at 2.

48. See Hodge v. West, 155 F.3d 1356, 1362 (Fed. Cir. 1998); see also Brown v. Gardner, 513 U.S. 115, 117-18 (1994).

49. See 38 C.F.R § 3.159 (2018); see also 38 C.F.R. § 21.1032 (2018).

50. See Frank S. Bloch, Representation and Advocacy at Non-Adversary Hearings: The Need for Non-Adversary Representatives at Social Security Disability Hearings, 59 WAsH. U. L.Q. 349, 355 (1981); see also Bernard Schwartz, Administrative Law 254 (Aspen Publishers, 1st ed. 1976) (supporting inquisitorial procedures for the Social Security disability system such as those used in the French inquisitorial system).

51. See 38 C.F.R. § 3.102 (2018).

52. Gilbert v. Derwinski, 1 Vet. App. 49, 53 (1991). 
a more favorable standard than Social Security disability or workers' compensation cases. ${ }^{53}$ If the VA finds that the evidence is in equipoise, the VA applies the "benefit of the doubt" doctrine and must resolve the claim in favor of the veteran. ${ }^{54}$

The VA's statutory duty to assist veterans in the development of claims is a powerful tool that veterans often use as leverage against the VA. ${ }^{55}$ Although veterans carry the burden of proving their claims, the VA must assist veterans in obtaining military and medical records, ${ }^{56}$ and must provide veterans with medical examinations to determine the outcome of their claims. ${ }^{57}$ The VA's duty to assist is a necessary feature of the system because indigent veterans who lack the resources to develop their own claims often lack access to private healthcare. Violations of the duty to assist are common, such as when the VA fails to provide veterans with an adequate examination, and are often the basis for remands from the Board and Veterans Court. ${ }^{58}$

Another unique feature of the benefits system is the absence of any statutory deadlines for filing claims or reopening previously closed claims. ${ }^{59}$ Veterans may file new claims at any point during their lifetime. ${ }^{60}$ After the VA closes a claim, a veteran may reopen a claim by submitting new and relevant evidence at any time. ${ }^{61}$ Even without new evidence, a veteran may allege clear error in a closed case resulting in a review of the case. ${ }^{62}$ The doctrine of res judicata exists, but is limited because veterans are permitted to submit new evidence at almost any stage of the claims process. ${ }^{63}$ As veterans age and develop new illnesses, they can submit new claims and evidence arguing that their illnesses are related to service.

Despite the liberal rules for adjudicating veterans' benefits, veterans have long been frustrated by the failures of Congress and the VA to address veterans' grievances. ${ }^{64}$ In 1932, shortly after the VA was created, World War I "Bonus Army" veterans marched on Washington to protest

53. See U.S. Dep't of Veterans Affairs, M21-1 Adjudication Procedures ManUAL, pt. III, subpt. IV, ch. 5, § A (2019), available at https://www.knowva.ebenefits.va.gov/ system/templates/selfservice/va_ssnew/help/customer/locale/en-US/portal/5544000000010 18/content/554400000014203/M21-1,-Part-III,-Subpart-iv,-Chapter-5,-Section-A-Princi ples-of-Reviewing-Evidence-and-Decision-Making [https://perma.cc/6ZMN-8JY9] [hereinafter M21-1 MANUAL, § A].

54. See Gilbert, 1 Vet. App. at 53.

55. See 38 U.S.C. $\S 5103 A$ (2012).

56. See id. $\S 5103 \mathrm{~A}(\mathrm{c})$.

57. See id. $§ 5103 \mathrm{~A}(\mathrm{~d})$.

58. See Nohr v. McDonald, 27 Vet. App. 124, 131-32, 135 (2014); see also Comer v. Peake, 552 F.3d 1362, 1369 (Fed. Cir. 2009); Moore v. Shinseki, 555 F.3d 1369, 1372-74 (Fed. Cir. 2009).

59. See Rory E. Riley, The Importance of Preserving the Pro-Claimant Policy Underlying the Veterans' Benefits Scheme: A Comparative Analysis of the Administrative Structure of the Department of Veterans Affairs Disability Benefits System, 2 Veterans L. Rev. 77, 85-88 (2010).

60. See 38 U.S.C. $\$ 1110$ (2012).

61. See 38 U.S.C. $\$ 5108$ (2012).

62. See id. §5103A(f).

63. See Norris v. West, 11 Vet. App. 219, 224 (1998).

64. See Ridgway, supra note 24 , at 19. 
delays in the award of veterans' readjustment bonuses that Congress had approved to compensate veterans for their absence from the workforce during the War. ${ }^{65} \mathrm{~A}$ violent clash between veterans and mobilized U.S. Army regiments became a symbol for the disenfranchisement of Depression-era veterans. ${ }^{66}$ Tension between veterans and the VA peaked after the Vietnam War, when the VA refused to recognize Post-Traumatic Stress Disorder (PTSD) and Agent Orange related illnesses caused by the War. ${ }^{67}$ It was not until 1980, when the American Psychiatric Association recognized PTSD as an illness, that veterans were able to obtain relief through the VA. ${ }^{68}$

In 1988, under extraordinary pressure from Veterans' Service Organizations (VSOs) and their veteran constituents to provide relief from the VA's arbitrary and capricious decision-making, Congress took its first steps toward using adversarial procedures to bring accountability to the process when it passed the Veterans' Judicial Review Act, which made the distribution of military benefits subject to review by specialized

65. See id.

66. See id. Prior to the reorganization of the benefits system under the New Deal, Congress was heavily involved in the distribution of veterans' benefits. Certain constituents who stood to gain from the system attempted to influence members of Congress. The process was viewed as politically charged and even corrupt. In 1924, Congress passed a bill granting bonuses to World War I veterans who were facing readjustment issues including decreased wages due to extended absences from the workforce. When payment of the bonuses was delayed, thousands of veterans demonstrated in Washington, D.C., in an event known as the Bonus Army. President Hoover ordered the Army Chief of Staff, Douglas MacArthur, and his two aides, Dwight Eisenhower and George Patton, to evict the veterans from Washington. The political backlash from the confrontation with impoverished veterans cost President Hoover the 1932 presidential election. President Franklin D. Roosevelt quickly reorganized the VA system under powers granted to him by the Economy Act of 1933, a piece of New Deal legislation that gave him the power to create a new system through executive orders. Ironically, President Roosevelt signed forty-one executive orders to slash veterans' benefits and create a $\$ 400$ million surplus to pay for his New Deal infrastructure projects. However, fearing further backlash from veterans' groups, Congress reversed many of Roosevelt's cuts.

67. See id. at 26. Severe lung illnesses and cancers related to burn pit exposures are plaguing Iraq and Afghanistan veterans. The VA refuses to recognize the link, as it did for PTSD and Agent Orange. See Leo Shane III, As Burn Pit Problems Linger, Advocates Worry VA and DoD Are Moving Too Slow, Military Times (June 7, 2018), https://www .militarytimes.com/veterans/2018/06/07/as-burn-pit-problems-linger-advocates-worry-vaand-dod-are-moving-too-slow/ [https://perma.cc/8F6D-JAEC]; Quil Lawrence, Veterans Claiming Illness From Burn Pits Lose Court Fight, NPR (Jan. 16, 2019), https://www.npr .org/2019/01/16/685657005/veterans-claiming-illness-from-burn-pits-lose-court-fight [https:// perma.cc/RR7N-2UDV] (the Supreme Court declined to hear an appeal from the Fourth Circuit, leaving intact a decision that KBR cannot be held liable for illness related to burn pits. KBR used burn pits to perform a contract with the military to dispose of trash); see also In re KBR, Inc., Burn Pit Litig., 893 F.3d 241, 264 (4th Cir. 2018).

68. See Ridgway, supra note 24 , at 27 . The VA continues to deny claims related to Agent Orange exposure, though it has conceded that some cancers are related to military service in Vietnam. See Richard Sisk, VA Renews Opposition to Agent Orange Benefits for Blue Water Navy Vets, Military.COM (Jan. 18, 2019), https://www.military.com/dailynews/2019/01/18/va-renews-opposition-agent-orange-benefits-blue-water-navy-vets.html? fbclid=IwAR1xL-qHQSDr-OChnPm0C6ExZDV-YIALsjzZwreUxcAh5u2F1ejTae1zsIY [https://perma.cc/DLT2-4EX4]. 
courts. ${ }^{69}$ The new law struck at the core of the non-adversarial system. Not surprisingly, the VA vehemently opposed judicial oversight and, as one scholar put it, the VA was brought "kicking and screaming" into the realm of due process. ${ }^{70}$ While judicial review brought transparency and accountability to a system that had operated for almost two hundred years in "splendid isolation," it was no panacea. ${ }^{71}$ The VA was now legally obligated to follow its own rules. But in many cases, its rules fell short of protecting veterans' interests. ${ }^{72}$

\section{The Harmful Effects of the Non-Adversarial System: A Case Study}

This section uses the case of Mathis v. Shulkin to describe how the veteran-friendly features of the veterans' benefits system are rendered ineffectual in the absence of meaningful processes by which veterans can challenge their application. ${ }^{73}$ The veteran-friendly feature at issue in this case is the VA's duty to provide medical exams for the purpose of establishing veterans' claims. The case demonstrates the limited means by which veterans can challenge duty to assist errors, as well as the judiciary's unwillingness to interfere with Congress's scheme for adjudicating VA benefits.

At issue in Mathis was whether the VA should benefit from a presumption that all medical examiners are qualified to render expert opinions in any type of disability benefits case. ${ }^{74}$ Freddie Mathis served in the U.S.

69. See Veterans' Judicial Review Act of 1988, Pub. L. No. 100-687, 102 Stat. 4105 (1988) (codified as amended in scattered sections of 38 U.S.C.). Not all veterans favored judicial review. Many veterans feared that judicial review would lead to the elimination of veteran-friendly doctrines. VSOs, such as the American Legion and Vietnam Veterans of America (VVA), disagreed on the reform effort, though VVA ultimately convinced Congress to pass a bill that tied judicial review to a popular proposal to make VA a cabinet department. See Ridgway, supra note 24, at 32.

70. See Lawrence B. Hagel \& Michael P. Horan, Five Years Under the Veterans' Judicial Review Act: The VA is Brought Kicking and Screaming into the World of Meaningful Due Process, 46 Me. L. Rev. 43, 43 (1994).

71. See Robert L. Rabin, Preclusion of Judicial Review in Processing Claims for Veterans' Benefits: A Preliminary Analysis, 27 Stan. L. Rev. 905, 905 (1975).

72. The VA has a host of system-wide problems that judicial review has not resolved, including: unreasonable delays in claims processing; mishandling of mail; failing to make timely notification of medical appointments and claims decisions to veterans; and failing to obtain records, such as records involving National Guard and Reserve personnel, mental health, private provider, special operations, and lost and missing records. See Veterans for Common Sense v. Shinseki, 678 F.3d 1013, 1016 (9th Cir. 2012) (exemplifying veterans unsuccessful challenges to unreasonable delays in the appellate process); see also U.S. Dep't of Veterans Affairs, Office of Inspector Gen., 14-04816-72, Veterans Benefits Administration: Review of Alleged Problems with Veterans Benefits Management System and Claims Processing 1-4 (Jan. 6, 2016); Leo Shane III, Lawsuit Demands VA Turn Over Missing Medical Records, Military Times (Apr. 20, 2015), https://www.militarytimes.com/veterans/2015/04/20/lawsuit-demands-va-turn-over-missingmedical-records/ [https://perma.cc/64J6-ECRA].

73. See Mathis v. Shulkin, 137 S. Ct. 1994, 1995 (2017) (Gorsuch, J., dissenting), cert. denied; see also Brief in Support of the Petition for a Writ of Certiorari, supra note 23.

74. See Mathis v. McDonald, 643 F. App'x 968, 972 (Fed. Cir. 2016), cert. denied sub nom. Mathis v. Shulkin, 137 S. Ct. 1994 (2017). 
Air Force from August 1980 to August $2002 .{ }^{75} \mathrm{He}$ was healthy for most of his military career, until the late 1990's when he routinely experienced fatigue, shortness of breath, and swelling in his left hand. ${ }^{76}$ Seven years after his discharge from service, Mr. Mathis was diagnosed with sarcoidosis, an inflammatory disease commonly affecting the lungs and lymph glands. ${ }^{77}$ Believing that his disease had been caused by "environmental exposures" while serving in the Air Force, Mr. Mathis filed a claim with the VA for disability benefits. ${ }^{78}$ A VA medical examiner specializing in family practice medicine reviewed Mr. Mathis's VA claims file and rendered a negative opinion, stating that Mr. Mathis's in-service pulmonary symptoms were not related to his sarcoidosis. ${ }^{79}$ The VA subsequently denied the claim. ${ }^{80}$

The VA enjoys an evidentiary presumption that it has properly chosen a medical examiner who is qualified through education, training, or experience to offer medical diagnosis, statements, or opinions in any disability benefits case. ${ }^{81}$ The common law rule, known as the "presumption of competency," has no provenance in statute or regulation..$^{82}$ Although the presumption is rebuttable, the VA provides no mechanism for veterans to obtain the credentials of VA examiners prior to a hearing in order to formulate a rebuttal. ${ }^{83}$

Mr. Mathis filed an appeal challenging the competency of the VA examiner. ${ }^{84} \mathrm{He}$ argued that the presumption of regularity, on which the presumption of competency rests, should only apply to routine, ministerial procedures. ${ }^{85} \mathrm{He}$ also challenged its application in the VA's non-adversarial process and argued that the presumption shifts the burden of proof to an "unsophisticated party" who lacks access to the evidence necessary to rebut the presumption. ${ }^{86}$

The Federal Circuit found merit in Mr. Mathis's arguments but declined to overrule the Veterans Court or its own precedent. The court noted that, in the line of cases applying the presumption of regularity to

75. Id. at 969.

76. See Appellant's Opening Brief at 4, Mathis, 643 F. App'x 968 (No. 2015-7094), 2015 WL 5086429, at *4.

77. Id.; see also Michael C. Iannuzzi et al., Medical Progress: Sarcoidosis, 357 N. ENGL. J. Med. 2153, 2153-65 (Nov. 22, 2007) (explaining that sarcoidosis is a disease that presents as tiny granules or nodules, called granulomas, that may form in one or more organs of the body, and can change the structure and functioning of the organs).

78. See Mathis, 643 F. App'x at 969.

79. See id.

80. See id. at 970.

81. See Rizzo v. Shinseki, 580 F.3d 1288, 1290-91 (Fed. Cir. 2009); see also Bastien v. Shinseki, 599 F.3d 1301, 1306 (Fed. Cir. 2010); Sickels v. Shinseki, 643 F.3d 1362, 1365-66 (Fed. Cir. 2011).

82. See Mathis v. Shulkin, 137 S. Ct. 1994, 1995 (2007) (Gorsuch, J., dissenting).

83. See id.

84. See Mathis, 643 F. App'x at 970.

85. See id. at 972 .

86. See id. at $972-73$. The majority of veterans are represented by VSO representatives who are not attorneys. See Bd. of Veterans' Appeals, Annual Report 2018, supra note 12, at 31. 
the VA's selection of medical examiners, there exists no discussion about whether the VA's procedures for selecting examiners are "regular, reliable, and consistent." ${ }^{87}$ It also noted that the VA's guidelines broadly recommend generalists but the record was silent as to the process by which examiners are selected. ${ }^{88}$ However, the court stated that it could not overrule its previous decisions upholding the presumption because it lacked jurisdiction to make factual findings regarding the competency of the examiner in question. ${ }^{89}$ The court called for the VA to consider an administrative rule that would create a clear standard for determining the sufficiency of an examiner's qualifications. ${ }^{90}$

The Supreme Court denied a petition for writ of certiorari, though two Justices issued opinions accompanying the Court's decision not to hear the case. Justice Sotomayor recognized the veteran's predicament in the case, calling the veteran's situation a "catch-22." ${ }^{91}$ However, because Mr. Mathis had failed to raise the competency issue at the Board and had not requested the credentials of his examiner, ${ }^{92}$ she was not willing to decide whether the presumption of competency or the VA's failure to provide examiners' credentials under the duty to assist violated due process. ${ }^{93}$ Waiting until such a case is presented, she wrote, would provide the Federal Circuit and the VA with an opportunity to "continue their dialogue." 94 Dissenting from the Court's decision, Justice Gorsuch warned that the significance of the issue to many veterans warranted the Court's immediate attention. ${ }^{95}$

Mathis is a prime example of how the non-adversarial process undercuts the veteran-friendly canons. Under the duty to assist, the VA must provide medical exams to claimants but veterans cannot meaningfully challenge expert testimony during the process. The VA maintains that it cannot permit interrogatories or cross-examinations of experts because Congress intended for the system to be non-adversarial. ${ }^{96}$ Veterans must therefore exhaust administrative remedies before pursuing litigation in the courts, often to correct simple errors. This highly ineffectual process has contributed to the current backlog of administrative appeals and has

87. See Mathis, 643 F. App'x at 974 . The court noted that the presumption of regularity was applied to the VA's mailing of notices to veterans and other ministerial, routine, and nondiscretionary tasks. $I d$. at 973 . Nowhere in the line of cases applying the presumption to the competency of medical examiners did any court perform an analysis to verify the selection and assignment of VA examiners. Id. at 974.

88. See id. at 974.

89. See id. at 975.

90. See id.

91. Mathis v. Shulkin, 137 S. Ct. 1994, 1994 (2007).

92. See id. The Veterans of Foreign Wars (VFW), a VSO that helps veterans file claims, represented Mr. Mathis at the Board but did not raise the competency issue. Mr. Mathis did not have legal counsel until his case reached the Veterans Court, at which time he challenged the presumption.

93. See id.

94. Id.

95. See Mathis, 137 S. Ct. at 1995 (Gorsuch, J., dissenting).

96. See Nohr v. McDonald, 27 Vet. App. 124, 131 (2014). 
manufactured an expert testimony crisis for the VA. ${ }^{97}$

\section{The Expert Testimony Crisis}

The impact of the Mathis case on veterans' benefits is significant. Almost every benefits case relies on expert medical testimony to establish a nexus between a veteran's current injury and his or her military service. ${ }^{98}$ The VA is permitted to consider a wide-variety of evidence when reviewing claims, but the nexus of an illness (i.e., whether it is "as likely as not" that an illness or injury was caused in service) is a determination that is reserved for medical examiners. ${ }^{99}$ Unfortunately, the Mathis case preserves the non-adversarial processes that contribute to the production of errant medical exams. A more detailed description of the medical exam process is necessary to understand how non-adversarial processes contributed to the crisis and to explore possible alternatives to the current procedures.

The VA provides veterans with "compensation and pension," or "C\&P" exams, pursuant to their duty to assist veterans develop benefits claims. ${ }^{100}$ A cadre of VA employees and contractors perform the exams. Examiners may be credentialed doctors, nurse practitioners, or physician assistants. ${ }^{101}$ Any provider employed by the VA is deemed qualified to conduct an exam and render an opinion on any claim, regardless of the nature of the claim or the provider's area of expertise. ${ }^{102}$

The purpose of the exam is to ensure "that the evaluation of the claimed disability will be a fully informed one." 103 VA adjudicators are "neither medical professionals nor attorneys," therefore medical opinions must contain a sufficient explanation of the medical findings so that a layperson can weigh and evaluate the evidence. ${ }^{104}$ In a typical day, a contractor will perform about seven or eight exams, rendering opinions on

97. The VA reports that there are currently 367,708 claims pending. See Veterans Benefits Administration Reports, U.S. Dep'T of Veterans Affairs, https://www.benefits.va .gov/reports/detailed_claims_data.asp?src=org_fb_dj [https://perma.cc/7UP4-FCKP] (last visited Mar. 4, 2019).

98. See 38 C.F.R. § 3.303(a) (2018). For a history of early VA medical examinations, see Jerry L. Mashaw, Federal Administration and Administrative Law in the Gilded Age, 119 YALE L.J. 1362, 1428-39 (2010).

99. M21-1 Manual, § A, supra note 53; see also Buchanan v. Nicholson, 451 F.3d 1331, 1336 (Fed. Cir. 2007); Barr v. Nicholson, 21 Vet. App. 303, 307-08 (2007); Colvin v. Derwinski, 1 Vet. App. 171, 175 (1991).

100. See 38 U.S.C. $\S 5103 A(d)(2012)$.

101. See 38 C.F.R. § 3.159(a)(1) (2018).

102. See Mathis v. McDonald, 643 F. App’x 968, 972 (Fed. Cir. 2016), cert. denied sub nom. Mathis v. Shulkin, 137 S. Ct. 1994 (2017).

103. Green v. Derwinski, 1 Vet. App. 121, 124 (1991) (holding that an adequate examination must include a review of the veteran's claims history).

104. See James D. Ridgway, Lessons the Veterans Benefits System Must Learn On Gathering Expert Witness Testimony, 18 FED. CIR. B.J. 405, 408 (2009) (discussing qualification of Regional Office adjudicators). 
multiple claims per exam. ${ }^{105}$ Examiners use Disability Benefits Questionnaires (DBQ) to answer routine questions about veterans' claimed disabilities, such as if a veteran has a current diagnosis, or if the condition impacts a veteran's ability to work. ${ }^{106}$

The process has significant flaws and often yields poor results. First, the VA relies exclusively on opinions from C\&P examiners, rather than VA primary care providers, for establishing service-connection. ${ }^{107}$ Within the VA system, C\&P examiners and medical providers serve discreet roles. Although the VA considers medical evidence from VA primary care providers, the VA does not elicit their opinions. ${ }^{108}$ Providers, who are often familiar with the patient's full medical history and are likely to have in-depth information that would assist adjudicators, have almost no role in the process. Presumably, the VA has chosen to shield VA providers from compensation issues to protect the physician-patient relationship. However, other disability benefits systems have relied on treating physicians' opinions without upsetting this relationship. ${ }^{109}$

The VA's preference for C\&P examiners' opinions contributes to its failure to obtain evidence from veterans' private physicians. ${ }^{110}$ The pre-

105. See Dennis Velez, M.D., Comp. and Pension Exam'r, Contractor for the Dep't of Veterans Affairs, Address at the National Law School Veterans Clinic Consortium Conference: C \& P Exams (Feb. 28, 2018).

106. See Disability Benefits Questionnaires (DBQS), U.S. Dep't of Veterans AfFAIRS, https://www.benefits.va.gov/compensation/dbq_disabilityexams.asp [https://perma .cc/8GRF-SPEJ] (last visited Mar. 6, 2019). Both VA and private medical examiners use DBQs. The forms were intended to standardize the opinions for VA and private exams and to ensure that providers include all the relevant information needed for an adequate medical opinion.

107. See Ridgway, supra note 104, at 419-20.

108. See id. at 421 . Examiners do not review the entire claims file. Rather, a predetermination team tabs relevant medical information in the veteran's file. There is no record of which documents in the claims file were tabbed, therefore it is impossible to know whether a medical examiner was directed to all relevant evidence in any case.

109. See 20 C.F.R. $\S 404.1520$ c (2018); see also Revisions to Rules Regarding the Evaluation of Medical Evidence, 82 Fed. Reg. 5844 (Jan. 18, 2017) (to be codified at 20 C.F.R. $\S 404.1520 \mathrm{c})$; Revisions to Rules Regarding the Evaluation of Medical Evidence, Soc. SECURITY ADMIN., https://www.ssa.gov/disability/professionals/bluebook/revisions-rules.html [https://perma.cc/Y4WW-XAAW] (last visited Mar. 6, 2019). The Federal Circuit rejected the argument that the opinions of a veteran's personal physicians should be accorded special deference. See White v. Principi, 243 F.3d 1378, 1380-81 (Fed. Cir. 2001). Until recently, Social Security Administration (SSA) adjudicators gave "controlling weight" to treating physicians' opinions under the "treating source rule." The SSA eliminated the treating source rule so that its adjudicators would not be required to give substantial weight to a treating physician's opinion regardless of the supportability and consistency of the opinion. According to the SSA, it eliminated the treating source rule to avoid the Ninth Circuit's application of the "credit-as-true" rule, a rule that the SSA said abdicated the decision-making authority of the SSA adjudicator and "sometimes result[ed] in the court ordering us to award benefits instead of remanding the case for further proceedings." Revisions to Rules Regarding the Evaluation of Medical Evidence, supra. Although the SSA abolished the treating source rule, it does consider a medical provider's relationship with the claimant, including the length of the relationship and the frequency of examinations, as well as the specialization of the medical provider, as important factors in the consideration of the medical opinion. See also Clare J. Horan, The Importance of Special Medical Consultants in the SSA Disability Determination Process: Analysis and Proposals, 102 Iowa L. REv. 1361, 1374 (2017).

110. See Ridgway, supra note 104, at 419. 
vailing view among VSOs is that the VA does not give equal weight to opinions by private physicians and C\&P examiners.111 In one study, about $50 \%$ of VA adjudicators reported having difficulty rating cases based upon private medical opinions. Only about $25 \%$ of the adjudicators reported having difficultly rating cases based on C\&P examiners' opinions. ${ }^{112}$ VSOs reported that the exact opposite was true. ${ }^{113}$ Regardless of whether the VA gives equal weight to private medical opinions, the appearance of a hierarchy of evidence gives veterans the impression that treating physicians' opinions are ignored or given less weight than VA opinions.

Second, the opinions that $\mathrm{C} \& \mathrm{P}$ examiners produce are often inadequate. An adequate opinion must be based on the medical examiner's knowledge and skill in analyzing the relevant data, in addition to the examiner's reasoned conclusions. ${ }^{114}$ In many instances, medical examiners are simply not able to review and identify the pertinent records in the patient's lengthy medical history upon which to provide an informed medical opinion. ${ }^{115}$ Furthermore, examiners often do not understand or are not aware of the reasons why the Board has remanded a case for another medical opinion. For example, the Board described the problem in a recent case this way:

In 2003, the Board remanded this case for a VA examination, requesting that the examiner identify any respiratory disorder, including a sinus disorder, state whether any such disability is related to active service, and provide a thorough rationale for any opinion expressed. Since the Board's 2003 remand, the Veteran has been afforded numerous VA examinations, as noted in the Joint Motion granted by the Court in January 2015. However, none have fully complied with the Board's 2003 remand directives. ${ }^{116}$

Unfortunately, the VA has not implemented a process to help examiners write opinions that meet the medical and legal requirements for an exam. ${ }^{117}$ Most examiners now use the VA's check-the-box DBQs, though examiners must still explain their conclusions in narrative form. In one survey, $56 \%$ of Regional Office adjudicators reported that inadequate ex-

111. See id. at 417.

112. See id.

113. See Daniel Harris, The CNA Corp., Findings From Raters and VSO's SuRvEYs 14 (May 2007), http://www.veteranslawlibrary.com/files/Commission_Reports/ CNA_May_2007_Survey_Results.pdf [https://perma.cc/7X4Q-VNSN].

114. See Nieves-Rodriguez v. Peake, 22 Vet. App. 295, 300 (2008); see also Buchanan v. Nicholson, 451 F.3d 1331, 1335-36 (Fed. Cir. 2006); Barr v. Nicholson, 21 Vet. App. 303, 310-12 (2007); Stefl v. Nicholson, 21 Vet. App. 120, 124 (2007); Stegall v. West, 11 Vet. App. 268, 270-71 (1998).

115. See Nieves-Rodriguez, 22 Vet. App. 295 at 305.

116. No. 1526657, 2015 WL 4690765, at*1 (Bd. Vet. App. June 23, 2015). Students in the Bob Parsons Veterans Advocacy Clinic at the University of Baltimore School of Law represented the veteran in this case. In 2017, the Veterans Court granted another joint motion for remand due to an inadequate examination. See No. 1704071, 2017 WL 1299706, at $* 7$ (Bd. Vet. App. Feb. 9, 2017).

117. See Ridgway, supra note 104 , at $409-11$. 
ams made it difficult to review claims. ${ }^{118}$ In 2013, the Board's chief executive told Congress, "[t]he adequacy of medical examinations and opinions, such as those with incomplete findings or supporting rationale for an opinion, has remained one of the most frequent reasons for remand." 119 Given the complexities of the exams, and the lack of communication between medical examiners and the Board, it is no surprise that the leading cause of Board remands is inadequate medical exams. ${ }^{120}$

The lack of communication between the adjudicators and medical providers is one of the most complex problems that the VA faces. ${ }^{121}$ It is extremely difficult for adjudicators to communicate complicated medical and legal questions to providers by relaying messages through Board decisions. The process is like a "game of telephone." 122 When a case is remanded from the Veterans Court, the Board issues orders directing the VA to take action to resolve issues in a case. The orders might ask the VA to obtain a medical opinion regarding whether a veteran's disability is as likely as not related to service or whether a veteran's disability was as likely as not aggravated by military service. ${ }^{123}$ Board orders are often complicated and may lack the necessary background that is necessary for a medical examiner to provide an adequate opinion. For example, the Board might provide a list of instructions to the Regional Office, such as the following: (1) conduct an exam to determine if specific disorders are present, and specifically address a previous VA treatment record documenting sinusitis; (2) provide an opinion as to whether the veteran's sinusitis and any other current disorders were incurred or aggravated by military service; and (3) if you find that the sinusitis or any other current disorders were incurred or aggravated by service, provide an opinion as to whether these service-connected disorders may have caused any other disorders. It is impossible to expect that such instructions will be properly understood and executed without further communication between the parties. Without an opportunity for clarification, there is a substantial risk that someone will misunderstand the remand orders, and the underlying justifications for them, and that the resultant opinion will be inadequate.

Congress created a streamlined system for adjudicating veterans' benefits, but the system is in turmoil. Favorable rules that indeed assist veterans and their families in obtaining the benefits they earned in service

118. Id. at 417 .

119. Why Are Veterans Waiting Years on Appeal?: A Review of the Post-Decision Process for Appealed Veterans' Disability Benefits Claims: Hearing before the Subcomm. on Disability Assistance and Mem'l Affairs of the Comm. on Veterans' Affairs, 113th Cong. 22 (2013) (statement of Laura H. Eskenazi, Executive-in-Charge of the Board of Veterans' Appeals).

120. See Ridgway, supra note 104 , at 416.

121. See id. at 421-23.

122. See James D. Ridgway, A Benefits System for the Information Age, 7 Veterans L. REV. 36, 53 (2015).

123. See, e.g., No. 1552016, 2015 WL 10004845, at *12 (Bd. Vet. App. Dec. 11, 2015); No. 1543733, 2015 WL 7875614, at *2 (Bd. Vet. App. Oct. 13, 2015); No. 1538484, 2015 WL 6939522, at *1-2 (Bd. Vet. App. Sept. 9, 2015); No. 1501503, 2015 WL 1194124, at *7-8 (Bd. Vet. App. Jan. 13, 2015). 
have been rendered ineffectual. Non-adversarial procedures that were meant to facilitate the award of benefits have instead delayed or thwarted equitable outcomes for veterans. The expert testimony crisis is a prime example of the non-adversarial process gone awry. Although Congress adopted judicial review of veterans' benefits cases, the courts are limited in what they can do. The next section explores the limitations of judicial review and examines why the courts have declined to interfere with the non-adversarial system despite the need for reform.

\section{WHY JUDICIAL REVIEW HAS FAILED TO PROTECT VETERANS' INTERESTS}

Congress's unique design for the veterans' benefits system has in many ways isolated it from other administrative law systems. The courts reviewing VA benefits decisions are distinct from general federal courts and have specific, limited statutory authority to review benefits decisions. ${ }^{124}$ These courts afford great deference to Congress's statutory scheme and are generally unwilling to impose formal or objective rules on the system. ${ }^{125}$ This section examines the courts' relatively limited role in the adjudication of veterans' benefits and the deference that courts afford to Congress's statutory scheme that keeps the non-adversarial system intact.

\section{A. The Limited Role of Appellate Courts}

Congress designed a unique system for judicial review of veterans' benefits decisions. As discussed above, initial claims are filed and adjudicated in VA Regional Offices, and adverse decisions can be appealed to the Board. ${ }^{126}$ Once a claimant has exhausted his or her administrative remedies at the Board, he or she may appeal to the Veterans Court. The Veterans Court has exclusive jurisdiction to review decisions by the VA Secretary. ${ }^{127}$ A claimant may appeal decisions by the Veterans Court to the Federal Circuit, and then to the Supreme Court. ${ }^{128}$ The exclusive jurisdiction of these courts insulates the VA from intervention by general federal courts that might upset the non-adversarial nature of the system.

To understand how these reviewing courts limit veterans' abilities to raise procedural challenges, it is necessary to discuss the distinct authority of these courts. The Veterans Court has the power to affirm, modify, or reverse a decision of the Board, or to remand a matter for further evidentiary development. ${ }^{129}$ The Veterans Court has no fact-finding authority and reviews the VA's fact determinations under the clearly erroneous

124. See 38 U.S.C. $\S \S 7252(a), 7292$ (2012).

125. See Walters v. Nat'l Ass'n of Radiation Survivors, 473 U.S. 305, 319-20 (1985).

126. See 38 U.S.C. $\$ 7104$ (2012).

127. See id. § 7252(a); see also Veterans for Common Sense v. Shinseki, 678 F.3d 1013, 1020 (9th Cir. 2012). General federal courts may hear cases involving constitutional issues that do not involve review of decisions by the VA Secretary.

128. See 38 U.S.C. $\$ 7292(\mathrm{~d})(1)$.

129. See id. § 7252(a). 
standard. ${ }^{130}$ The Federal Circuit may only review questions of law and is prohibited from reviewing challenges to factual determinations or challenges to law or regulations as applied to the facts of a particular case. ${ }^{131}$ Veterans may bring suit in general federal court, but these courts only have jurisdiction to review facial statutory or constitutional challenges that do not fall within the exclusive jurisdiction of the Veterans Court or the Federal Circuit. ${ }^{132}$ That is, they may not decide any issue that would require review of decisions affecting the provision of benefits to individual claimants. ${ }^{133}$ This framework has been extremely successful in limiting judicial review to bite-sized issues that do not upset the nonadversarial nature of the benefits scheme.

While the Veterans Court has the authority to decide a broad range of issues affecting the administration of veterans' benefits, it has exercised its authority narrowly. ${ }^{134}$ For example, the Veterans Court has the power to modify or reverse Board decisions, but it has used that power sparingly. The court disposes most of its cases through remands back to the Board, rarely reversing Board decisions. ${ }^{135}$ The Veterans Court will generally remand cases with faulty or "inadequate" medical opinions back to the Board, citing its statutory prohibition on de novo review of the facts as the reason for not reversing a Board decision and granting benefits. ${ }^{136}$ Likewise, the Veterans Court has been criticized for issuing too many "memorandum decisions," or single-judge opinions that have no precedential authority. ${ }^{137}$ Scholars have urged the court to consider whether more cases should be referred to three-judge panels for precedential decisions. ${ }^{138}$ And, until recently, the Veterans Court maintained that it had no power to hear class action lawsuits, meaning veterans were left to chal-

130. See id. $\$ \S 7261(\mathrm{a})(4), 7261(\mathrm{c}), 7292(\mathrm{~d})(2)$. The Veterans Court is specifically prohibited from conducting de novo review of benefits decisions by the VA Secretary.

131. See id. $\$ 7292$.

132. See id. $\$ \$ 511(b)(4), 7252(a), 7292(c)$; see also Veterans for Common Sense, 678 F.3d at 1033-34 (discussing a split in the circuit courts regarding whether 38 U.S.C. $\$ 511$ prohibits veterans from bringing facial constitutional challenges to acts of Congress in federal district court).

133. See, e.g., Veterans for Common Sense, 678 F.3d at 1034.

134. See Michael P. Allen, Commentary on Three Cases from the Federal Circuit and the Court of Appeals for Veterans Claims As We Approach Twenty-Five Years of Judicial Review of Veterans' Benefits, 5 Veterans L. Rev. 136, 151 (2013).

135. See id. at 150.

136. See id. at 152.

137. See id. at $157-58$.

138. See id. at 158. The Veterans Court considers six factors when deciding whether to refer a case to a three-judge panel to issue a precedential opinion, including if the case on appeal is of

relative simplicity and (1) does not establish a new rule of law; (2) does not alter, modify, criticize, or clarify an existing rule of law; (3) does not apply an established rule of law to a novel fact situation; (4) does not constitute the only recent, binding precedent on a particular point of law within the power of the Court to decide; (5) does not involve a legal issue of continuing public interest; and (6) the outcome is not reasonably debatable.

Frankel v. Derwinski, 1 Vet. App. 23, 25 (1990). 
lenge unfair procedures on a case-by-case basis. ${ }^{139}$

Claimants who are disillusioned with the Veterans Court's limited power to resolve broader issues have brought suit in general federal courts, though they have mostly been unsuccessful. ${ }^{140}$ Federal courts have denied challenges alleging that lengthy delays in providing benefits to claimants violate due process, including delays in providing health care to claimants with PTSD and other mental health disorders. ${ }^{141}$ In fact, very few veterans' cases can be heard in general federal court because of statutory bars limiting the review of benefits decisions to the Veterans Court and Federal Circuit. ${ }^{142}$ The limited number of cases that general federal courts have jurisdiction to hear are decided in favor of the government, often because the courts are unwilling to interfere with Congress's statutory scheme.

\section{B. Deference to Congress and Limited Due Process FOR Disabled Veterans}

Judicial review of agency action is a limited form of review. ${ }^{143}$ As the Supreme Court emphatically stated in Perez v. Mortgage Bankers Association, "Beyond the APA's minimum requirements, courts lack authority 'to impose upon [an] agency its own notion of which procedures are "best" or most likely to further some vague, undefined public good." "144 Notably, Congress did not extend APA procedures to the veterans' benefits system for fear that doing so would upset its non-adversarial under-

139. But see Monk v. Shulkin, 855 F.3d 1312, 1318-21 (Fed. Cir. 2017) (holding Veterans Court has the authority to hear class action lawsuits under the All Writs Act, other statutory authority, and the Veterans Court's inherent powers).

140. See, e.g., Veterans for Common Sense v. Shinseki, 678 F.3d 1013, 1015-16 (9th Cir. 2012) (the court did not have jurisdiction to review claimant's plea to remedy delays in the system because the issue was related to benefits decisions that are only reviewable by the Veterans Court and the Federal Circuit); see also Hicks v. Small, 69 F.3d 967, 970 (9th Cir. 1995) (the court did not have jurisdiction to review a veteran's state tort claim against a VA doctor because the court was precluded from reviewing the case under 38 U.S.C. $\S 511$ ); Zuspann v. Brown, 60 F.3d 1156, 1159-60 (5th Cir. 1995) (the court lacked jurisdiction to review a veteran's challenge to a denial of benefits on constitutional grounds); Chinnock v. Turnage, 995 F.2d 889, 892 n.2 (9th Cir. 1993) (holding that 38 U.S.C. $\$ 511$ precluded judicial review of the VA's interpretation of a regulation that affected the denial of a veteran's disability benefits). But see Hanlin v. United States, 214 F.3d 1319, 1321 (Fed. Cir. 2000) (the Federal Circuit has jurisdiction to review an attorney's fee claim that is unrelated to the veteran's benefits decisions).

141. See Veterans for Common Sense, 678 F.3d at 1016; see also Viet. Veterans of Am. v. Shinseki, 599 F.3d 654, 656, 661 (D.C. Cir. 2010) (veterans' advocacy groups lacked standing to bring an action against the VA seeking declaration that the average time it took the VA to process veterans' claims for service-related disability benefits violated the Administrative Procedure Act and the Due Process Clause); Beamon v. Brown, 125 F.3d 965, 972 (6th Cir. 1997) (veterans have an alternate adequate remedy in Veterans Court, which has exclusive jurisdiction over constitutional challenges to benefits decisions by the VA).

142. See 38 U.S.C. $\$ \S 511,7252$ (a), 7292 (2012).

143. See Adrian Vermeule, Deference and Due Process, 129 Harv. L. Rev. 1890, 1930-31 (2016); see also Mashaw, supra note 98, at 1465.

144. Perez v. Mortg. Bankers Ass'n, 135 S. Ct. 1199, 1207 (2015) (quoting Vt. Yankee Nuclear Power Corp. v. Nat. Res. Def. Counsel, Inc., 435 U.S. 519, 549 (1978)). 
pinnings. ${ }^{145}$ As such, due process challenges in the VA system are analyzed using the well-known test announced by the Supreme Court in Mathews v. Eldridge. ${ }^{146}$ The factors that must be weighed in determining whether a deprivation violates an individual's due process rights are: (1) the private interest affected by the government action; (2) the risk of erroneous deprivation, including the value of additional procedural safeguards; and (3) the government's interest, including the fiscal and administrative burdens of any additional procedural safeguards. ${ }^{147}$ Further, as Justice Powell announced in Mathews, "In assessing what process is due in this case, substantial weight must be given to the good-faith judgments of the individuals charged by Congress with the administration of social welfare programs that the procedures they have provided assure fair consideration of the entitlement claims of individuals." 148

This section examines due process challenges in the veterans' benefits system. It explores the utility of the Mathews $v$. Eldridge balancing test in analyzing due process challenges in the VA system and concludes that it is the wrong test for determining procedural rights for veterans.

In 1985, in the heat of the due process revolution, the Supreme Court heard a blockbuster case that involved the right of veterans to retain counsel in pursuing disability benefits claims. ${ }^{149}$ The issue in Walters $v$. National Association of Radiation Survivors was whether 38 U.S.C. $\S 3404(c)$ violated due process by imposing a $\$ 10$ fee limitation on attorneys who represent veterans in benefits cases. ${ }^{150}$ The fee limitation effectively eliminated attorneys from representing claimants, a restraint on liberty and speech that appellees argued violated the Due Process Clause of the Fifth Amendment and their First Amendment rights. ${ }^{151}$ The U.S. District Court for the Northern District of California held that the statute was unconstitutional and entered a preliminary injunction barring the VA from imposing the fee limitation. ${ }^{152}$

The district court looked to Mathews for guidance in analyzing the due process question. The issue in Mathews was whether the termination of a recipient's Social Security disability benefits payments prior to an evidentiary hearing violated due process. ${ }^{153}$ Mathews was factually similar to a case the Court had decided seven years earlier, Goldberg v. Kelly, in

145. See Veterans' Judicial Review Act of 1988, Pub. L. No. 100-687, 102 Stat. 4105 (codified as amended in scattered sections of 38 U.S.C.); see also Explanatory Statement of the Veterans' Judicial Review Act of 1988, 134 Cong. Rec. 31,477 (1988), reprinted in 1988 U.S.C.C.A.N. 5782, 5843.

146. See Mathews v. Eldridge, 424 U.S. 319, 348-49 (1976).

147. See id. at 335.

148. Id. at 349 .

149. See Walters v. Nat'l Ass'n of Radiation Survivors, 473 U.S. 305, 307 (1985).

150. See id.

151. See id. at 308.

152. See id. Prior to 1988, judicial review of VA decisions was precluded by 38 U.S.C. $\S 211$ (a). However, in Johnson v. Robison, the Supreme Court held that district courts have jurisdiction to hear cases involving constitutional challenges to the VA claims system. See Johnson v. Robison, 415 U.S. 361, 366 (1974).

153. See Mathews, 424 U.S. at 323. 
which the Court held that a recipient of welfare benefits was entitled to an evidentiary hearing prior to termination of his benefits. ${ }^{154}$ Distinguishing Goldberg, the Mathews Court noted that the private interest at stake in disability cases was somewhat less than in need-based benefits cases. The Court also noted the reduced risk of error in disability cases because of the reliability of unbiased medical reports used to decide such cases. ${ }^{155}$ Therefore, the Court held that a predetermination hearing was not required in Mathews. ${ }^{156}$

Despite the benefits distinctions discussed in Mathews, the district court in Walters held that the fee limitation violated veterans' due process rights. ${ }^{157}$ The court engaged in an exhaustive balancing of the Mathews factors, noting that veterans' interests in receiving benefits was significant and that many recipients are totally disabled and are not able to obtain gainful employment. ${ }^{158}$ The court also noted that, without counsel, veterans incurred a significant risk of forfeiting their rights due to the complex technical medical and legal issues involved in the cases. ${ }^{159}$ The court therefore concluded that the fee limitation violated the Due Process Clause. ${ }^{160}$

The Supreme Court reversed, stating that the district court "went seriously awry in assessing the constitutionality of $\S 3404$." 161 According to the Court, the crux of the issue was the proper weight to afford the government's interest. ${ }^{162}$ After rebuking the district court for "cavalierly dismissing" the preservation of the 123 year-old fee limitation rule, the Court considered the consequences of disrupting Congress's informal, non-adversarial ex parte system of adjudicating benefits. ${ }^{163}$ Cataloging the government's interests, the Court stated that, if claimants were represented by counsel, the VA would require more government lawyers; the role of the hearing officer would become akin to that of a trial judge; and lawyers, advancing clients' claims by any ethical means, would prolong the already lengthy decision-making process. ${ }^{164}$ In short, the Court afforded substantial deference to Congress's interests in maintaining an in-

154. See Goldberg v. Kelly, 397 U.S. 254, 266-71 (1970).

155. See Mathews, 424 U.S. at 343-45.

156. See id. at 349.

157. See Nat'l Ass'n of Radiation Survivors v. Walters, 589 F. Supp. 1302, 1323 (N.D. Cal. 1984), rev'd, 473 U.S. 305 (1985).

158. See id. at 1314.

159. See id. at 1319-20.

160. See id. at 1327.

161. Walters v. Nat'l Ass'n of Radiation Survivors, 473 U.S. 305, 320 (1985).

162. See id. at 321-22.

163. See id. at 323.

164. See id. at 324-25. Analyzing the risk of error, the Supreme Court applied the generality standard articulated in Mathews. Id. at 330. As Justice Powell explained, the fairness of procedures turns on the risk of error as applied in the generality of cases, not the rare exceptions. Id. at 321. In Walters, the Supreme Court estimated that "complex" cases accounted for less than two percent of the Board's caseload and less than one-half percent of Regional Office cases. Id. at 329. The Court concluded that complex cases were the rare exception, not the norm, and therefore the fee limitation satisfied the Mathews test. Id. at 330. 
formal and flexible system and refused to question the wisdom of denying counsel to disabled veterans. ${ }^{165}$

Twenty-four years after Walters, the Federal Circuit decided a case that signaled a potential shift in how courts might review claimants' due process challenges. ${ }^{166}$ In Cushman v. Shinseki, the court considered whether an applicant's due process rights were violated when the VA considered improperly altered medical records to deny his claim. ${ }^{167}$ The facts were straightforward: Mr. Cushman was awarded partial disability benefits for a back condition but was denied other benefits. ${ }^{168}$ Years later, Mr. Cushman discovered that the official medical records that the VA had relied upon to deny his claims had been improperly altered. ${ }^{169}$ The VA conceded that the documents had been fraudulently altered but continued to deny his claims. ${ }^{170}$ On appeal, the Board found that the altered documents constituted harmless error, and the Veterans Court affirmed the Board's decision. ${ }^{171}$ The Federal Circuit vacated the Veterans Court's decision, finding that improperly altered material evidence constituted a clear due process violation. ${ }^{72}$ More importantly, the court held that veterans' benefits are "nondiscretionary, statutorily mandated benefits," and that applicants for benefits have an entitlement to veterans' benefits that "is a property interest protected by the Due Process Clause of the Fifth Amendment." 173

Scholars called Cushman a watershed decision because never before had the court recognized an applicant's property interest in disability

165. See id. at 326. Three years after the Supreme Court's decision in Walters, Congress passed the Veterans' Judicial Review Act, an act that abolished the $\$ 10$ fee limitation rule. See Veterans' Judicial Review Act of 1988, Pub. L. No. 100-687, 102 Stat. 4105 (codified as amended in scattered sections of 38 U.S.C.). However, under the Act, lawyers were prohibited from charging a fee until after the VA had issued an adverse decision and the claimant had filed a Notice of Disagreement. See 38 U.S.C. $\$ 5904$ (c)(1) (2012). As of February 19, 2018, pursuant to the Veterans Appeals Improvement and Modernization Act of 2017, veterans may hire an attorney after an initial decision on a claim. See Veterans Appeals Improvement and Modernization Act, Pub. L. No. 115-55, 131 Stat. 1105 (2017) (codified as amended in scattered section of 38 U.S.C.).

166. See Cushman v. Shinseki, 576 F.3d 1290, 1292 (Fed. Cir. 2009).

167. See id.

168. See id. at 1292-93. Philip Cushman served in the Marine Corps combat infantry battalion and was injured while fortifying a bunker in Vietnam. He suffered from a spinal injury when a heavy sack fell on his spine. It took the VA three years to review his initial claim and to develop evidence before granting service-connection for his back injury. For the next twenty years, Mr. Cushman filed claims and appeals related to his back injury.

169. See id. at 1293-94. Mr. Cushman discovered discrepancies in his medical records when he found there were two versions of the documents. The altered documents contained additional statements that understated his disability. The Portland VA Regional Office conceded the error and destroyed the altered documents. A fraud investigation was opened but closed shortly thereafter.

170. See id. at 1294.

171. See id. at 1294-95. The Board denied Mr. Cushman's claim on grounds that there was no evidence to establish that the Board specifically relied on the altered documents to deny Mr. Cushman's claim.

172. Id. at 1300 . The Federal Circuit held that the presentation of improperly altered material evidence constituted a due process violation in analogous cases in other circuit courts.

173. See id. at 1298. 
benefits or applied constitutional due process protections to that interest. ${ }^{174}$ Prior to Cushman, due process principles were exclusively a creature of statute, codified in laws and regulations adopted by Congress and the VA to ensure the "fair adjudication" of veterans' benefits. ${ }^{175}$ Judicial review of due process challenges was chiefly a question of whether the VA had followed its own procedures and regulations. ${ }^{176}$ After Cushman, due process issues were clearly a matter of constitutional interpretation. The distinction was significant because the Federal Circuit has broader statutory authority to review factual determinations in cases that present constitutional issues. ${ }^{177}$ The Cushman decision, therefore, broadened the Federal Circuit's jurisdiction to include review of run-of-the-mill factual determinations in cases that Congress did not intend for Federal Circuit review. ${ }^{178}$ In other words, the Federal Circuit could review the factual determinations necessary to determine what process is due under $\mathrm{Ma}$ thews $v$. Eldridge and potentially sustain due process challenges for veterans. ${ }^{179}$

Despite the hype, the Cushman decision did not impact judicial review in the way that scholars predicted. In the last decade, there have been few due process cases that have expanded rights for veterans or resolved systemic problems in the benefits system. ${ }^{180}$ There are two reasons for this. First, the due process analysis still requires judges to keep a thumb on the scale for the government's interests. Second, judges continue to apply the Mathews test as a zero-sum calculation in which the increase in procedural rights for veterans results in a decrease in the informality and flexibility of the system. Judges are not willing to accept the notion that

174. See Michael P. Allen, Due Process and the American Veteran: What the Constitution Can Tell Us About the Veterans' Benefits System, 80 U. Cin. L. REv. 501, 526-28 (2011).

175. Id. at 502 n.14; see also 38 U.S.C. § 501(a) (2012); 38 C.F.R. § 3.103 (2018).

176. See Michael P. Allen, The Law of Veterans' Benefits 2008-2010: Significant Developments, Trends, and a Glimpse into the Future, 3 VETERANS L. REV. 1, 44 (2011); see also Austin v. Brown, 6 Vet. App. 547, 552 (1994); Thurber v. Brown, 5 Vet. App. 119, 125 (1993); Fugere v. Derwinski, 1 Vet. App. 103, 107 (1990).

177. See 38 U.S.C. § 7292(d)(2); see also Gambill v. Shinseki, 576 F.3d 1307, 1310-11 (Fed. Cir. 2009).

178. See Allen, supra note 174, at 520-21.

179. See id. at 521.

180. See id. at 515-18; see also Mathis v. McDonald, 643 F. App'x 968, 975 (Fed. Cir. 2016) (denying a challenge to the presumption of competency, a common law rule that the Board applies to presume that all VA medical examiners are competent to perform medical exams, unless rebutted by the veteran); Sprinkle v. Shinseki, 733 F.3d 1180, 1182 (Fed. Cir. 2013) (holding that a veteran was not denied fair process by not providing him with a copy of a medical examiner's opinion until fewer than thirty days before the Board's decision); Edwards v. Shinseki, 582 F.3d 1351, 1358 (Fed. Cir. 2009) (Rader, J., concurring) (rejecting the court's holding in Cushman that applicants for benefits have a property interest protected by the Due Process Clause of the Fifth Amendment, stating "I perceive that this court has run before the Supreme Court sounded the starting gun on property rights for applicants."); Justice v. McDonald, No. 14-2502, 2015 Vet. App. LEXIS 1541, at *10-11 (Nov. 13, 2015) (denying a challenge alleging that a veteran's due process rights were violated when the VA failed to provide the veteran with a copy of his medical exam and adverse decision). 
procedural rights for veterans are actually compatible with the veteranfriendly system.

The Federal Circuit's decision in Gambill v. Shinseki illustrates the zero-sum problem. ${ }^{181}$ In Gambill v. Shinseki, the Federal Circuit considered whether the VA's prohibition against interrogatories violated the Due Process Clause of the Fifth Amendment. ${ }^{182} \mathrm{Mr}$. Gambill alleged that he had a constitutional right to submit interrogatories to the ophthalmologist on whose opinion the VA relied to deny Mr. Gambill's claim. The court decided the case on other grounds, but two of the judges wrote concurring opinions addressing the constitutional question. ${ }^{183}$ Judge Bryson wrote that due process does not require that claimants be given the right to confront medical examiners. ${ }^{184}$ Relying heavily on the Supreme Court's decision in Walters, he emphasized that due process is a flexible concept, and that the process required depends on the importance attached to the interests in the case. ${ }^{185} \mathrm{He}$ noted that veterans' interests in disability benefits are not granted on the basis of need, and therefore should be weighted less than claimants' interests in welfare payments. ${ }^{186}$ Judge Bryson then outlined the various non-adversarial procedures of the benefits system and, citing the Walters decision, stressed that "great weight must be accorded to the Government interest at stake here." 187

Judge Moore rejected the zero-sum calculation endorsed by Judge Bryson and instead compared the veterans' disability system to the Social Security disability system. ${ }^{188}$ She refused to accept that Congress intended to give disabled veterans fewer rights than disabled citizens who had not borne the battle. ${ }^{189}$ She questioned Judge Bryson's reasoning that interrogatories make the veterans' benefits system more adversarial "because by the time a veteran has the need to question a doctor, that doctor has already provided an opinion adverse to the veteran's interests." 190

181. See Gambill v. Shinseki, 576 F.3d 1307, 1313 (Fed. Cir. 2009).

182. See id. at 1310. Mr. Gambill asserted that he has a constitutional right to submit interrogatories to the medical examiner.

183. See id. at 1312-13. The Federal Circuit avoided the constitutional question by holding that even if Mr. Gambill had been denied a due process right to submit interrogatories, he suffered no harm because no medical evidence was presented that could establish a nexus between Mr. Gambill's cataracts and his head injury. Id. The Veterans Court avoided the constitutional question because Cushman had not yet been decided when the case was first appealed. The Veterans Court affirmed the Board's decision on "fair process" grounds. Id. at 1310 .

184. See id. at 1313 (Bryson, J., concurring).

185. See id.

186. See id. at 1314 (distinguishing Mathews v. Eldridge, 424 U.S. 319 (1976), on grounds that disabled veterans do not rely on disability payments for daily subsistence as welfare recipients do and therefore have a reduced property interest that permits less formal procedures)

187. Id.

188. See id. at 1326 (Moore, J., concurring).

189. See id.

190. Id. 
Judge Moore's concurring opinion is significant because it rejects the dichotomy that the veterans' benefit system is either adversarial or nonadversarial. Judge Moore noted that Congress blurred these lines when, after Walters, Congress implemented judicial review of benefits cases and gave veterans the right to hire an attorney. ${ }^{191}$ As scholars have noted, the post-Walters benefits system is a combination of formal and informal rules that could be construed as both adversarial and non-adversarial. ${ }^{192}$ If judges dispensed with the adversarial-non-adversarial construct, they could more appropriately consider the need for additional procedural safeguards to address the risk of error in the system. In other words, the Mathews test could be an effective test for determining when judicial-type procedures must be imposed on the VA, but only if judges avoid the either-or construct and recognize the need to balance the system with more procedural safeguards for veterans. ${ }^{193}$

\section{The VA's Duty to Assist Failures}

"In the veterans' uniquely claimant friendly system of awarding compensation, breaches of the duty to assist are at the heart of due process analysis. If the Constitution provides no protection against the occurrence of such breaches, then the paternalistic interest in protecting the veteran is an illusory and meaningless assurance."194

As discussed above, while veterans have a right to the fair adjudication of their claims under the Fifth Amendment of the Due Process Clause, courts have been reluctant to interfere with Congress's statutory scheme. As such, the fair and equitable distribution of benefits is dependent on the protections provided by the VA's regulatory process. In lieu of adversarial mechanisms, such as discovery and depositions, to aid claimants in the development of evidence, veterans are dependent on the VA to provide them with documents under a doctrine known as the "duty to assist." 195 Generally, the VA has a duty to assist veterans in the preparation of their claims. ${ }^{196}$ Appellate courts have avoided constitutional questions about veterans' rights to discovery and depositions by instead reviewing whether the VA failed to assist veterans in the development of their

191. See id. at 1328.

192. See Allen, supra note 174, at 531; see also Michael P. Allen, The United States Court of Appeals for Veterans Claims at Twenty: A Proposal for a Legislative Commission to Consider Its Future, 58 CATH. U. L. REv. 361, 378-79 (2009); Ridgway, supra note 104, at 423 .

193. But see Stacey-Rae Simcox, Thirty Years After Walters the Mission Is Clear, the Execution Is Muddled: A Fresh Look at the Supreme Court's Decision to Deny Veterans the Due Process Right to Hire Attorneys in the VA Benefits Process, 84 U. Cin. L. Rev. 671, 736 (2016) (reexamining Walters's assumption that the VA system is non-adversarial and calling for a reevaluation of veterans' rights to counsel under the Mathews factors).

194. Cook v. Principi, 318 F.3d 1334, 1354 (Fed. Cir. 2002) (Gajarsa, J., dissenting).

195. See 38 U.S.C. § 5103A (2012).

196. See id. $\S 5103 \mathrm{~A}(\mathrm{a})$. The scope of the VA's duty to assist veterans is ambiguous and perennially litigated by claimants challenging the VA's failure to act in various stages of the adjudicative process. 
claims in individual cases. ${ }^{197}$ This piecemeal approach to judicial review is laborious and slow and has done little to resolve structural problems within the VA.

Two cases are illustrative. As noted earlier, the Mathis case dealt with the presumption of competency that the Board affords VA medical examiners in disability benefits cases. ${ }^{198}$ Judge Hughes found no issue with the limited presumption because, under the duty to assist, "a veteran may always request information to challenge an examiner's competency from the regional office or the Board." 199 The opinion is noteworthy because it misconstrues how the duty to assist actually works. The VA may be ordered to produce an examiner's credentials if a veteran raises a specific objection to the examiner's competency. ${ }^{200}$ However, absent a court order, the VA is not inclined to produce any information about its examiners. The VA adjudicator's manual, the M21-1, specifically addresses requests for examiners' credentials. ${ }^{201}$ The manual states, "[t]he mere fact that such a communication is received does not mean that the examination is insufficient or in need of clarification, or that there is a further duty to assist to obtain records or another examination." 202 The manual further states that adjudicators are to read the substance of such communications and to check that the examiners' opinions comply with VA regulations, but that they should not respond to interrogatories. ${ }^{203}$ Hence, veterans have no means to obtain evidence with which to rebut the presumption of competency. Judge Hughes's opinion also ignores the VA's lengthy processing times and the years of litigation involved in resolving a competency challenge. Disabled veterans are suffering from serious illnesses

197. See, e.g., Nohr v. McDonald, 27 Vet. App. 124, 134 (2014) (the court did not address whether the Board violated the veteran's Fifth Amendment due process rights when it refused to allow the veteran to question the VA medical examiner, instead framing the issue as a duty to assist error).

198. See Mathis v. McDonald, 643 F. App'x 968, 971 (Fed. Cir. 2016).

199. Mathis v. McDonald, 834 F.3d 1347, 1349 (Fed. Cir. 2016) (Hughes, J., concurring) (denying petition for rehearing en banc).

200. See Bastien v. Shinseki, 599 F.3d 1301, 1307 (Fed. Cir. 2010).

201. See U.S. Dep't of Veterans Affairs, M21-1 Adjudication Procedures ManUAL, pt. III, subpt. IV, ch. 3, § D (2019), available at https://www.knowva.ebenefits.va.gov/ system/templates/selfservice/va_ssnew/help/customer/locale/en-US/portal/5544000000010 18/content/554400000015812/M21-1-Part-III-Subpart-iv-Chapter-3-Section-D-Examina tion-Reports?query=Nohr\#2 [https://perma.cc/AM4G-UFYZ] [hereinafter M21-1 MANUAL, § D].

202. Id. (emphasis added).

203. See id. This is an unreasonable demand on VA adjudicators. The law governing the competency of medical examiners and the adequacy of medical opinions is a complex area. For example, the M21-1 manual instructs adjudicators to read Nohr v. McDonald and Bastien v. Shinseki. See id. In Bastien, the Federal Circuit held that, because the VA is not required to affirmatively establish the competency of its examiners, veterans must raise specific objections to an examiner's qualifications to rebut the presumption of competency. Bastien, 599 F.3d at 1307. VA adjudicators are, therefore, expected to decide whether correspondence from the claimant's attorney, which could be in the form of interrogatories, raises legitimate concerns with respect to an examiner's qualifications. VA Adjudicators should not be expected to resolve such issues without significant legal training. Nonetheless, the M21-1 directs adjudicators to read case law to resolve these issues. 
and often cannot wait for a decision by the Veterans Court. ${ }^{204}$ Finally, the opinion ignores the fact that the credentials of examiners are an important factor in determining the weight of the opinions. VA adjudicators routinely consider providers' credentials when determining the probative weight of private opinions. ${ }^{205}$ An equitable weighing of evidence cannot be made without knowing the credentials of VA examiners.

The Nohr case provides another example of courts using the duty to assist to avoid constitutional questions. Mr. Nohr filed a claim for a dysthymic disorder based on a statement from his private physician that his depression may have originated during service. ${ }^{206}$ Between February 2003 and July 2012, the VA requested four medical opinions that the Board subsequently determined to be inadequate because they did not provide the substantive information to determine service-connection. ${ }^{207}$ In each case, the claim was remanded for another medical opinion. ${ }^{208}$ For example, in a July 2011 opinion, the examiner described the symptoms of dysthymic disorder, and then stated that "Mr. Nohr 'ha[d] not endorsed any traumatic event other than his ordinary military duty' and opined that 'there is obvious and manifest evidence that [Mr. Nohr's] preexisting dysthymic disorder was not aggravated by service.'"209 On appeal to the Veterans Court, the parties agreed that the opinion was conclusory and not supported by an adequate rationale, and jointly remanded the case for another opinion. ${ }^{210}$

In the fourth and final medical opinion, the examiner, Dr. Feng, provided an addendum to her opinion that stated, "Respectfully, while I recognize my personal limitation, the Board should seek for the next expert opinion if this examiner's report still is not satisfied by the Board review." ${ }^{11}$ Mr. Nohr submitted interrogatories to the Board asking the examiner to explain her statement regarding her "personal limitation." 212 In

204. See Life Cycle of an Appeal, supra note 33. It can take more than seven years to obtain a decision from the Veterans Court.

205. See Ridgway, supra note 104, at 424.

206. See Nohr v. McDonald, 27 Vet. App. 124, 126 (2014). A dysthymic disorder is a mood disorder characterized by extended episodes of depression.

207. See id. at 126-27.

208. See id.

209. Id. at 127 (alterations in original) (quoting Record of Proceedings at 112, Nohr, 27 Vet. App. 124 (No. 13-1321)).

210. See id.

211. Id.

212. See id. at 127-28. Mr. Nohr requested that the examiner answer eleven questions: (1) State your full name. (2) State your place of employment and the address.

(3) Provide a copy of your most recent and up[-] to[-]date curriculum vitae. (4) Provide a copy of the Board ... request letter to you that you refer to in the first line of your medical opinion dated July 30, 2012[,] for James A. Nohr, (here[in]after "the veteran". (5) Provide copies of all written correspondence between you and the Board regarding the [v]eteran including, but not limited to e-mails, letters, faxes, and the like. (6) Provide a copy of the transcript from the July 30, 2012[,] interview between you and the [v]eteran. (7) Provide a copy of all handwritten notes made by you during your interview with the [v]eteran from July 30, 2012. (8) Explain the phrase "personal limitation" referred to in the last paragraph from your July 30, 2012[,] opin- 
April 2013, the Board issued a decision denying the claim and refusing to answer Mr. Nohr's interrogatories, stating that "there is no VA regulatory authority for interrogatories, and it is stressed that the benefits system is non-adversarial in nature." 213

On appeal, the Veterans Court vacated the Board's decision and remanded the case for further development. ${ }^{214}$ Judge Schoelen noted the Board's "knee-jerk reaction" to the discovery tool used by lawyers and commented that the Board's preoccupation with non-adversarial procedures "prevented the Board from seeing the forest for the trees." 115 She noted that Mr. Nohr's interrogatories raised legitimate questions about the VA examiner's competency, the adequacy of her opinion, and the VA's duty to assist Mr. Nohr in obtaining documents to challenge the VA examiner's competency. ${ }^{216}$ She further cautioned the veterans bar and the VA to proceed carefully "so as not to unravel Congress's desire to preserve and maintain the unique character and structure of the paternalistic, nonadversarial veterans' benefits system."217 However, she did not address the constitutional question of whether the Due Process Clause of the Fifth Amendment entitled Mr. Nohr to confront the examiner. ${ }^{218}$

The Nohr case demonstrates the court's unwillingness to upset the nonadversarial process. But more importantly, it showcases the "hamster wheel" effect that is created by the VA's procedures for developing medical evidence. ${ }^{219}$ Four inadequate exams over a ten-year period is astounding, though hardly unexpected, given the substantial risk of miscommunication between VA adjudicators and medical examiners.

Judicial review has brought transparency and accountability to the VA, but it has not resolved the delays and adjudication errors that have become commonplace. Reviewing courts have limited jurisdiction to intervene in the non-adversarial process, and deference to Congress's statutory scheme has undoubtedly helped preserve the status quo. Of course, Congress has the power to make sweeping changes to the process but reaching agreement on such issues with the VA and VSOs is a formidable undertaking. The VA could use its rule-making authority to create

\footnotetext{
ion of the veteran. (9) Explain your etiology for use of the terms "obvious and manifest" when referring to clear and unmistakable evidence referred to in the second paragraph of your July 30, 2012[,] opinion of the veteran. (10) Please elaborate on what a "typical dysthymic disorder picture" is, as you refer to it in the second paragraph of your July 30, 2012[,] opinion of the [v]eteran. (11) Please elaborate further on what you consider to be "ordinary military duty" as you so state in the second paragraph of your July 30, 2012[,] opinion of the [v]eteran.

Id. (alterations in original).

213. Id. at 128 .

214. See id. at 135 .

215. Id. at 131 .

216. See id. at 132-33.

217. Id. at 131 .

218. See id. at 134.

219. See Coburn v. Nicholson, 19 Vet. App. 427, 434 (2006) (Lance, J., dissenting) (stating that repeated remands perpetuate the "hamster-wheel" reputation of veterans law).
} 
more balanced procedures that would preserve the non-adversarial system but add procedural safeguards to protect the interests of veterans. The next section explores the structure and features of other claims adjudications systems and examines how the VA might implement procedural safeguards used in those systems.

\section{BALANCING THE NON-ADVERSARIAL SYSTEM WITH ADVERSARIAL PROCEDURES}

The distribution of veterans' benefits has grown ever more complicated over the last several decades. Since the implementation of judicial review in 1988, Congress has marched steadily toward a more legalistic and technical administrative system for adjudicating benefits. 220 Today, the benefits system is governed by a complex web of legal and medical principles that require veterans and VA adjudicators to have an intimate knowledge of the substance and mechanics of the rules to adjudicate claims.

While Congress and the VA have introduced more formal rules, the VA has not implemented a strategy to help its adjudicators keep up with the law. In 1994, Lawrence Hagel wrote an article about the VA's sluggish reaction to decisions by the courts. ${ }^{221}$ For fiscal years 1977 to 1989 , Hagel noted that the Board overturned decisions of the Regional Offices $29.5 \%$ of the time due to improper adjudication. ${ }^{222}$ By 1992, the reversal rate had grown to $66.2 \% .^{223}$ Today, the Board's reversal rate is about $74 \% .{ }^{224}$ It is no surprise that the Board reverses so many Regional Office decisions when adjudicators in those offices lack the medical and legal expertise to properly adjudicate the claims. The VA's resources are too few, and its mission too expansive, for the VA to provide the necessary training and additional personnel to improve claims processing. This section compares the veterans' benefits system with other disability systems and examines how procedural rights for veterans could provide a check on high-risk processes, facilitate the timely corrections of errors, and reduce the number of claims on appeal.

220. See Allen, supra note 174, at 530-31. For example, Congress abolished the limitation on attorneys' fees, a change that resulted in more lawyers providing legal services to veterans in the claims process. See 38 C.F.R $\$ 14.636$ (c) (2018). Lawyers may collect a reasonable fee for services provided after the veteran receives an initial decision in the case. With the passage of the Veterans' Claims Assistance Act of 2000, Congress imposed a host of legal requirements on the VA that increased the VA's notice and duty to assist obligations to veterans. See Veterans Claims Assistance Act, Pub. L. No. 106-475, 114 Stat. 2096 (2000) (codified as amended in scattered sections of 38 U.S.C.).

221. See Hagel \& Horan, supra note 70, at 51. Judge Hagel is a retired Chief Judge of the U.S. Court of Appeals for Veterans Claims.

222. Id. at 52. For the period from 1977-1989, Hagel calculated the Board's reversal rate by combining the total of the average percentage of cases remanded $(17.5 \%)$ and the average percentage of cases actually granting a benefit (13.25\%). See id. at 52 n.43.

223. Id. For the year 1992, Hagel calculated the Board's reversal rate by combining the total percentage of cases remanded in 1992 (50.5\%) and the percentage of cases actually granting a benefit $(15.7 \%)$.

224. See Bd. of Veterans' Appeals, Annual Report 2018, supra note 12, at 31. The author calculated the Board's reversal rate by combining the total percentage of cases remanded $(38.8 \%)$ and the average percentage of cases actually granting a benefit $(35.8 \%)$. 


\section{A. Rights of Claimants in Other Disability Benefits Systems}

The accurate and reliable production of expert testimony is a critical feature of the American civil legal system. Tort suits, to which VA claims are sometimes compared, often require experts to resolve medical issues. ${ }^{225}$ Rules of procedure permit opposing counsel to cross-examine expert witnesses on the basis of their knowledge, skill, expertise, training, and education to render opinions. ${ }^{226}$ The process is an important feature of the American court system given the weight that adjudicators afford such evidence.

Likewise, administrators providing for the mass adjudication of benefits in other systems find it possible, indeed preferable, to incorporate trial-like rights into their processes. The Social Security disability system and many state workers' compensation systems provide claimants with procedural rights that are akin to trial rights. These rights have been implemented in critical phases of the claims process, such as the development of expert testimony, to ensure the proper and efficient resolution of claims. While these two systems are not perfect, their processes for developing expert testimony provide a model for a more balanced non-adversarial VA claims system. ${ }^{227}$

The Social Security disability system processes even more claims than the VA, making it a good model for comparison. The Social Security Administration (SSA) manages several programs that provide disability benefits to individuals, including the Social Security Disability Insurance (SSDI) program and the Supplemental Security Income (SSI) program. ${ }^{228}$ In 2015, SSA decided about 2.5 million SSDI claims, of which 1.6 million required medical opinions. ${ }^{229}$ That same year, the VA decided about 1.28 million claims ${ }^{230}$ and processed at least one million requests for medical examinations. ${ }^{231}$ Despite its higher volume claims, the SSA provides more procedural protections for its claimants than the VA provides for veterans.

225. See RIDGWAy, supra note 24 , at 169.

226. See, e.g., Fed. R. Evid. 702; see also Md. R. Evid. 5-702.

227. See Erica M. Woehl, Social Security Administration Disability Discrepancies: The Debate Between Street-Level Bureaucrats and Administrative Law Judges, 91 N.D. L. REv. 353, 354-55 (2015); see also Jon. C. Dubin, Overcoming Gridlock: Campbell After a Quarter-Century and Bureaucratically Rational Gap-Filling in Mass Justice Adjudication in the Social Security Administration's Disability Programs, 62 Admin. L. Rev. 937, 964-71 (2010).

228. See Social Security Act, 42 U.S.C. $\S \S 301-307$ (2016).

229. Social Sec. Admin., Annual Statistical Report on the Social Security Disability Ins. Program 153 (2016).

230. Life Cycle of an Appeal, supra note 33.

231. U.S. Dep't of Veterans Affairs, Office of Inspector Gen., 09-02135-107, Veterans Benefits Administration: Audit of VA's Efforts to Provide Timely Compensation and Pension Medical Exams 7-8 (Mar. 17, 2010). The 2010 report found that the VA had not established procedures to capture the examination workload. At the time, the VA tracked exam requests rather than actual exams completed. Currently, neither exam requests nor the actual number of examinations is reported in the VA's annual report to Congress. See Annual Benefits Report Fiscal Year 2016, supra note 23. 
Social Security claims procedures mirror VA procedures in many ways. ${ }^{232}$ Initial claims for benefits are processed at Regional Offices managed by each state. ${ }^{233}$ If a claim is denied, claimants may request reconsideration or elect to have their case decided by an Administrative Law Judge (ALJ) ${ }^{234}$ An ALJ is an SSA employee who presides at administrative hearings on behalf of the SSA Commissioner. Like VA hearings, SSA hearings are non-adversarial, meaning there is no lawyer for the SSA opposing the claim. The ALJ "administer[s] oaths, examin[es] witnesses, receiv[es] evidence, mak[es] findings of fact, and decid[es] whether an individual is or is not disabled." 235

The most notable difference between SSA and VA hearings is the applicability of the Administrative Procedures Act (APA) to SSA hearings. ${ }^{236}$ The APA's hearing provisions provide a statutory basis for claimants to present oral or documentary evidence, to submit rebuttal evidence, and "to conduct such cross-examination as may be required for a full and true disclosures of the facts." 237 In SSA hearings, medical experts provide ALJ's with impartial expert opinions, testifying by telephone, video teleconference, or through the use of interrogatories. 238 Although the hearing is non-adversarial, experts testify much as they would in court. ALJs question experts about their impartiality and their qualifications for providing an expert opinion. ${ }^{239}$ Claimants also have the opportunity to challenge an expert's competence and may cross-examine an expert regarding their opinion. ${ }^{240}$

Veterans have far fewer procedural rights in the VA system. In an effort to preserve the non-adversarial nature of the system, Congress did not adopt $\S 7$ of the APA, the section governing hearing adjudications, when it passed the Veterans Judicial Review Act of 1988. ${ }^{241}$ As a result,

232. See Social Sec. Admin., Medical Expert Handbook 1 (Aug. 2017), https:// www.ssa.gov/appeals/public_experts/Medical_Experts_(ME)_Handbook-508.pdf [https:// perma.cc/9BD5-6WSM] [hereinafter MEdicAl ExPERT HaNDBOOK].

233. See id. at 2.

234. See id. at 3.

235. See id.

236. See Gambill v. Shinseki, 576 F.3d 1307, 1323 (Judge Bryson compared § 7(c) of the APA, 5 U.S.C. $\$ 556(\mathrm{~d})$ (2012), to the Explanatory Statement of the Veterans' Judicial Review Act of 1988, 134 Cong. Rec. 31,477 (1988), reprinted in 1988 U.S.C.C.A.N. 5782, 5843 , noting that "Congress made clear at the time of the Veterans' Judicial Review Act of 1988 that it did not want the provisions of section 7(c) of the Administrative Procedure Act to apply to veterans' disability compensation proceedings.").

237. Administrative Procedures Act $\$ 7,5$ U.S.C. $\$ 556(d)$ (2018).

238. See Medical Expert Handbook, supra note 232, at 5-6.

239. See id. at 5. Experts submit their curriculum vitae for the record as a matter of course.

240. See id. at 6.

241. See generally Veterans' Judicial Review Act of 1988, Pub. L. No. 100-687, 102 Stat. 4105 (codified as amended in scattered sections of 38 U.S.C.). The Veterans' Judicial Review Act (VJRA) is silent as to whether veterans have a right to cross-examination. Legislative history of the VJRA includes the following comment: "The Committees intend that those informal procedures be continued and that the title 5 procedures relating to adjudications continue to be inapplicable." See Explanatory Statement of the Veterans' Judicial Review Act of 1988, 134 Cong. Rec. 31,477 (1988), reprinted in 1988 U.S.C.C.A.N. 5782, 5843. However, the context of that passage refers to VA travel board procedures, not hear- 
veterans do not have the right to cross-examine medical experts, ${ }^{242}$ nor do they have the right to compel interrogatories. ${ }^{243}$ As such, veterans are not able to directly challenge the credibility of expert witnesses during hearings through an examination of their qualifications, experience, or training. 244

Workers' compensation systems also rely on informal rules of procedure to resolve claims, though the involvement of employers' insurance companies and their lawyers clearly makes the process more adversarial. ${ }^{245}$ Nonetheless, even under relaxed rules, these systems apply fair play rules that include the right to cross-examination, rules against ex parte statements, and rules preserving evidence on the record. ${ }^{246}$ In federal workers' compensation cases, under the Longshore and Harbor Workers' Compensation Act, injured defense contractors working on overseas military installations have the right to discovery, subpoena witnesses, depose, compel interrogatories, and cross-examine witnesses. ${ }^{247}$

There is no reason why disabled veterans should not be afforded the same hearing rights as disabled people in other forums. Proponents of the current VA system fear that the adoption of APA hearing procedures would result in veterans losing veteran-friendly rules such as the "as likely as not" standard, VA's duty to assist, and the right to file claims at virtually any time. ${ }^{248}$ But, as discussed above, APA rules are congruent with veteran-friendly doctrines and do not present a conflict. There is no reason why APA hearing procedures used in civil administrative systems could not be incorporated into the VA system. In fact, it is counter-intuitive that a non-adversarial system for veterans affords fewer procedural rights to claimants than similar civilian systems.

ing procedures. Nonetheless, the legislative history is often cited as the basis for rejecting proposals to expand hearing rights for veterans. Interestingly, the same legislative history contemplates Congress's intent for claimants to have the right to submit interrogatories. However, that right did not appear in the final version of the Act. See id. at 31,476.

242. See Nohr v. McDonald, 27 Vet. App. 124, 129-31 (2014).

243. See id.

244. See M21-1 Manual, § D, supra note 201.

245. See 3 Lex K. Larson \& Thomas A. Robinson, Larson's Workers' CompensaTION LAw, Desk Edition § 127.11(3)(b) (Matthew Bender \& Company, Inc., 2018).

246. See id. $\$ 127.11(3)($ a); see also 39 Jon. L. Gelman, Workers' Compensation Law § 26.15 (Thompson West, 3d ed. 2018); Md. Code Regs. § 14.09.03.09 (2018). It is common for injured workers in state systems to have the right to subpoena and crossexamine medical experts.

247. See 20 C.F.R. $\$ 725.458$ (2018) (injured coal miners have the right to take depositions and interrogatories of medical experts); see also 29 C.F.R. $\$$ 18.601-.615 (2018). Under the Longshore and Harbor Workers' Compensation Act, defense contractors have the right to a hearing before the Office of the Administrative Law Judges (OALJ). The APA governs OALJ hearings and provides claimants with rights to discovery, to subpoena and depose witnesses, to compel interrogatories, and to cross-examine witnesses.

248. See, e.g., Riley, supra note 59, at 85. 


\section{B. The Adoption of APA Hearing Procedures FOR VA MEDical Exams}

The adoption of APA hearing provisions to aid adjudicators in the development of medical opinions could provide tremendous relief to the process. James Ridgway has observed that, "Much time and effort is wasted in veterans benefits cases by dividing up the evidence-gathering and adjudication processes and creating excessive separation between adjudicators and physicians." 249 Indeed, the bifurcation of the roles of treating providers and medical examiners has created significant problems for the VA. ${ }^{250}$ Ridgway suggests two reforms that would improve the process of developing expert testimony without upsetting the non-adversarial process: (1) adopting APA hearing procedures that would facilitate communication between adjudicators and physicians; and (2) better use of VA technology. ${ }^{251}$

Ridgway argues that APA hearing procedures would improve the quality of medical opinions, resulting in fewer errant opinions. ${ }^{252}$ The APA provides basic procedural rights for Social Security disability claimants that veterans do not have. For example, Social Security claimants have the right to an attorney at any stage of the claims process, ${ }^{253}$ and the right to cross-examination, subpoena witnesses, and compel interrogatories during hearings. ${ }^{254}$ Claimants have unfettered access to medical treatment records and expert opinions, and can therefore make informed decisions about their cases. ${ }^{255}$

Importantly, APA procedures could be implemented without upsetting the non-adversarial process. ${ }^{256}$ Like the veterans system, the Social Security system is considered non-adversarial; that is, there is no attorney for the SSA who argues against the claim. As Ridgway suggests, VA adjudicators could conduct inquisitorial interviews with medical examiners, similar to the way hearings are conducted in the Social Security disability benefits system. ${ }^{257}$ In Social Security hearings, the medical expert is present and answers questions from the ALJ and the claimant about his or her qualifications and opinion. ${ }^{258}$

249. Ridgway, supra note 104, at 422-23.

250. See id. at 422.

251. See id. at 418.

252. See id. at 423-28.

253. See 20 C.F.R. $\$ \S 404.1700-.1720$ (2018). VA claimants are generally limited to legal representation until they file an appeal.

254. See 5 U.S.C. $\S 556(d)$ (2012). These tools are helpful to adjudicators who must determine the weight of expert medical testimony.

255. See James T. O'Reilly, Burying Caesar: Replacement of the Veterans Appeals Process Is Needed to Provide Fairness to Claimants, 53 Admin. L. Rev. 223, 239 (2001). Notably, the provisions of the APA also provide for exhaustion of remedies, ripeness for judicial review, and deference to agency expertise. This author does not advocate adopting those provisions, as they would conflict with many of the doctrines in the VA system. See id. at 235-37.

256. See Ridgway, supra note 104, at 423.

257. See id.

258. See Medical Expert Handbook, supra note 232, at 5-6. 
These interviews would have obvious and immediate effects on the VA system. Foremost, adjudicators could pose questions about the case, including questions raised by the claimants, directly to the medical examiners. This single change would reduce the number of claims that are remanded for errors and shorten the time that veterans must wait for decisions. $^{259}$ Furthermore, interviews would reduce the need for additional exams to address issues not raised during initial exams. This would eliminate an adjudicator's arduous task of weighing multiple and often conflicting medical opinions. ${ }^{260}$ Interviews would also encourage examiners to elaborate on their opinions, which would further aid in the development of adequate opinions. Most importantly, interviews would give veterans more assurance that adjudicators are considering all the relevant medical evidence in their cases and not simply relying on opinions that support their conclusions. ${ }^{261}$

One drawback of the proposal is the time that it would add to the production of medical opinions. The number of medical exams that the VA conducts for benefits purposes has grown significantly in the last few years. Between 2012 and 2013, the VA's production of medical opinions increased from 1.79 million to 2.17 million opinions, a $20 \%$ increase. ${ }^{262}$ By 2017, the VA's production had increased to over 3.6 million opinions. ${ }^{263}$ The increase is largely due to the overall increase in the number of veterans receiving disability compensation. From 2000 to 2013, recipients of disability compensation rose by almost $55 \% .{ }^{264}$ Given this growth, the administrative burden of conducting interviews is a concern.

However, the adoption of medical interviews arguably would result in a net decrease in the number of exams. As discussed above, opinions would be more thoroughly supported and developed, and examiners would have a better understanding of opinion criteria, thereby reducing the need for re-exams. Examiners would have more direction and input from adjudicators and claimants, and could therefore more quickly identify and focus on relevant issues. And not every case would require an interview, as the process would be reserved for more complex cases. In short, medical interviews would produce better medical opinions, thereby reducing the notoriously circulative process of evidence development.

259. See Ridgway, supra note 104 , at $417-18$.

260. See Nieves-Rodriguez v. Peake, 22 Vet. App. 295, 305 (2008) (the Board's assignment of more probative weight to the VA examiners' opinions than to the private examiner's opinion was appropriate where the private examiner overlooked key documents in the claims file).

261. See Ridgway, supra note 104, at 427. Ridgway suggests recording the interviews not only to create a record, but also to bring transparency to the process.

262. RIDGWAY, supra note 24, at 422.

263. U.S. Dep't of Veterans Affairs, Nat'l Cemetery Admin., Benefits and Burial Programs and Departmental Administration 187 (2019), https://www.va .gov/budget/docs/summary/fy2019VAbudgetvolumeIIIbenefitsBurialProgramsAndDept mentalAdministration.pdf [https://perma.cc/J5Z3-UVK6].

264. U.S. Cong. Budget Off., Veterans' Disability Compensation: Trends and Policy Options 1 (Aug. 2014) http://www.cbo.gov/sites/default/files/cbofiles/attachments/ 45615-VADisability_1.pdf [https://perma.cc/Q8SC-PPDE]. 
As Ridgway points out, the VA already owns technology that could be used to conduct interviews between geographically separated examiners and adjudicators. The VA currently uses videoconferencing technology to hold Board hearings for veterans in Regional Offices across the country. ${ }^{265}$ Transcripts from hearings are uploaded to the veterans' claims files, making them easily available to the veterans. ${ }^{266}$ The VA could leverage its technology to conduct hearings between medical examiners and Regional Office adjudicators. ${ }^{267}$ Because the technology is already used in a similar fashion at Board hearings, the cost to implement such procedures would be minimal.

Without question, the VA must reform its process for developing medical expert testimony. Medical interviews, like those used in Social Security disability proceedings, offer significant advantages to the VA. Importantly, the VA has videoconferencing technology that could be used to conduct medical interviews for geographically separated participants. Pursuant to its administrative rulemaking authority, the VA could implement the process with minimal administrative costs. ${ }^{268}$

\section{Other Proposals for Resolving Inefficiency IN THE VA SYSTEM}

Some scholars have suggested that appellate review by the Veterans Court is the root cause of inefficiency and delay in the VA system. ${ }^{269}$ They argue that Article III courts should hear veterans' cases rather than a specialized Article I court with limited powers. Other scholars argue that the Veterans Court is the proper forum to review VA decisions but that the Veterans Court should exercise its authority more broadly. This section examines scholars' proposals for court reform and considers the likelihood that such proposals can resolve inefficiencies and delays in the system. ${ }^{270}$

The most radical proposals argue that veterans' benefits cases should be heard in U.S. district courts rather than the Veterans Court. James T. O'Reilly proposes combining VA and Social Security claims into a single disability benefits system. ${ }^{271}$ Under his proposal, VA Regional Offices would adjudicate veterans' claims, but appeals would go to Social Secur-

265. See Ridgway, supra note 122 , at 54.

266. See Ridgway, supra note 104, at 426.

267. See id.

268. See 38 U.S.C. $\S 303$ (2012).

269. See Wishnie, supra note 37, at 1737-38. Both the VA and the SSA have a fourtiered system of appellate review, including two agency-level reviews and two levels of appellate court reviews, that scholars argue is unnecessary and burdensome for veterans.

270. In 2017, Congress passed the Veterans Appeals Improvement and Modernization Act to address delays in the appellate process. The Act went into effect in February 2019. The Act created various appeal lanes to help the VA prioritize its claims, though it did not address any of the procedural issues raised in this article. Therefore, a review of the Act is not within the scope of this article. See Veterans Appeals Improvement and Modernization Act, Pub. L. No. 115-55, 131 Stat. 1105 (2017) (codified as amended in scattered section of 38 U.S.C.).

271. O'Reilly, supra note 255, at 243. 
ity ALJs, then to the Social Security Appeals Council, and then to U.S. district court. ${ }^{272}$ The model is attractive because, as discussed above, it affords claimants the procedural safeguards provided by the APA. ${ }^{273}$ O'Reilly argues that APA norms would bring veterans' law jurisprudence into line with federal administrative law, which would foster accuracy, efficiency, and accountability in the VA system. ${ }^{274}$

In a similar proposal, Michael Wishnie argues that the VA should adopt the immigration model of appeals. ${ }^{275}$ Claimants in the immigration system may appeal an adverse decision by the Board of Immigration Appeals (the highest administrative level of review in the U.S. immigration system) directly to the federal courts of appeals. By circumventing district courts and specialized courts of review, the system avoids the redundant layers of judicial review in the VA and SSA systems. ${ }^{276}$ Judicial review by Article III courts would also eliminate the problem of isolating veterans from broader developments in administrative and constitutional law. ${ }^{277}$ Moreover, it would reduce the backlog of claims caused by the recirculation of claims between the Veterans Court and the Board. ${ }^{278}$

Other scholars argue that delays in the system could be remedied if the Veterans Court simply exercised broader fact-finding and decision-making authority. Judge Michael Allen argues that the Veterans Court could reduce the number of remands by taking a narrower view of the statutory prohibition on the Veterans Court's fact-finding authority. ${ }^{279}$ Doing so would allow the Veterans Court to reverse more Board decisions and order the award of benefits. ${ }^{280} \mathrm{He}$ also recommends that the Veterans Court reexamine how the criteria in Frankel v. Derwinski are being applied in determining whether cases are referred to three-judge panels for precedential opinions. ${ }^{281}$ Such changes would provide more predictability and continuity in the system and reduce the number of cases on appeal arising from the increasing backlog of cases at the VA. Finally, Judge Allen suggests that the Veterans Court should consider the context in which it decides cases and issue opinions that provide practical rules and clear guidance to the pro se claimants that make up the majority of the courts' appellants. ${ }^{282}$

272. Id. O'Reilly introduced the concept of melding the two systems almost two decades ago. Practitioners have generally supported the idea of adopting Social Security hearing procedures. See also Robin J. Artz, What Veterans Would Gain from Administrative Procedure Act Adjudications, 62 FED. Law. 14, 15 (2015), http://www.fedbar.org/Re sources_1/Federal-Lawyer-Magazine/2015/August/Columns/Focus-on-Veterans-and-Mili tary-Law.aspx?FT=.pdf [https://perma.cc/2ZMG-X347].

273. O'Reilly, supra note 255 , at 225.

274. Id. at 225-27.

275. Wishnie, supra note 37 , at 1738 .

276. See id. at 1739.

277. Id.

278. See O'Reilly, supra note 255 , at 227.

279. Allen, supra note 134 , at 151.

280. See id. at 152.

281. See id. at 158; see also Frankel v. Derwinski, 1 Vet. App. 23, 25-26 (1990).

282. Allen, supra note 176, at 60-61. 
Of course, there are legal and political considerations associated with O'Reilly's and Wishnie's proposals to dramatically alter the appellate court landscape. First, swapping out the Veterans Court and Federal Circuit for district and circuit courts would require an act of Congress. The legal and political maneuvering that would be required to achieve such a feat is beyond the scope of this article. ${ }^{283}$ However, even if this herculean task were possible, it would not change the status quo. Plaintiffs have challenged the VA's statutory scheme in U.S. district courts, and the courts have predictably ruled in favor of the VA. In Veterans for Common Sense v. Shinseki, two non-profit organizations brought suit in the U.S. District Court for the Northern District of California challenging the delays in the VA benefits system experienced by veterans with mental health disabilities. ${ }^{284}$ Among other things, the organizations argued for an accelerated appeals process for mental health claims. ${ }^{285}$ The court dismissed the issues involving benefits decisions on the grounds that it lacked jurisdiction to hear those issues. ${ }^{286}$ On the due process challenge, the court held that the Due Process Clause does not demand a more expedient system for veterans with mental illness. ${ }^{287}$ Reviewing the $M a$ thews factors, the court concluded that "Congress purposely designed a non-adversarial system ... [that] should be kept as informal and nonadversarial as possible." 288

Article III courts are generally bound by the same legal doctrines as the Veterans Court and Federal Circuit and will defer to Congress's interests under the Mathews factors in much the same manner. It is true that Article III courts have a broader stream of cases that expose their judges to related fields such as employment, public benefits, and disability law. ${ }^{289}$ But the problem remains that the courts' deference to Congress insulates the non-adversarial system from judicial influence.

The most direct means of balancing the non-adversarial system with procedural rights to protect veterans' interests is through VA rulemaking. The VA has the authority and the technology to supplement the process for developing expert testimony with APA hearing procedures. The goal of the non-adversarial system is well meaning. Making the system func-

283. See Ridgway, supra note 24 , at 22-23. The trio of the U.S. House Veterans Affairs Committee, the VSOs, and the VA share such close ties that they are collectively known as the "Iron Triangle."

284. See Veterans for Common Sense v. Shinseki, 678 F.3d 1013, 1015-16 (9th Cir. 2012).

285. Id. at 1016 .

286. Id. Generally, only the CAVC, Federal Circuit, and the Supreme Court are authorized to review decisions by the VA Secretary affecting the provision of benefits. However, facial challenges to statutory schemes unrelated to individual benefits may be brought in general federal courts. For example, a challenge to the absence of system-wide procedures that are necessary to afford due process could be brought in U.S. district court. Proposals to drastically alter the appellate court structure would require Congress to revise the jurisdiction of these courts.

287. See id. at 1035-36.

288. Id. (citing Walters v. Nat'l Ass'n of Radiation Survivors, 473 U.S. 305, 323-24 (1985)).

289. See Wishnie, supra note 37, at 1736. 
tional, however, depends on whether the VA is willing to embrace modern procedural norms.

\section{CONCLUSION}

Today's disabled veterans face a crisis. They are plagued by systemic problems in the VA benefits system that they have no way of addressing. Endless delays caused by a convoluted process for developing medical evidence are at the root of the problem. Paradoxically, Congress's veteran-friendly scheme for distributing benefits is preventing veterans from addressing these issues. The courts providing judicial review are generally powerless to resolve these issues. As a result, veterans sit in limbo waiting for resolution of their cases by an agency searching for leadership and direction.

Scholars have offered a range of proposals to address these problems. Conservative proposals contemplate a more expansive role for judges reviewing veterans' claims, ${ }^{290}$ while radical proposals call for a complete overhaul of the system. ${ }^{291}$ Both types of proposals are dependent upon the will of Congress. However, through administrative rulemaking, the VA could address the problematic issue of inadequate medical examinations. By adopting APA procedures in the development of medical opinions, the VA could improve communication between adjudicators and medical examiners and reduce the risk of inadequate medical opinions that extend the adjudicative process.

The veteran-friendly provisions of the veterans' benefits systems reflect the unique relationship this nation has with its defenders. At a minimum, the VA system should adopt the rights and privileges afforded to disabled civilians seeking benefits. The nation owes more than a debt of gratitude to its warriors. Congress and the VA must be vigilant in protecting veterans' interests, especially when the courts have limited power to do so.

290. See Allen, supra note 134 , at 163.

291. See O'Reilly, supra note 255 , at 249-54. 